ACCEPTED MANUSCRIPT

\title{
Study of biomorphic calcium deficient hydroxyapatite fibres derived from a natural Harakeke (Phormium Tenax) leaf fibre template
}

To cite this article before publication: Humair Ahmed Siddiqui et al 2020 Bioinspir. Biomim. in press https://doi.org/10.1088/1748-3190/abbc64

\section{Manuscript version: Accepted Manuscript}

Accepted Manuscript is "the version of the article accepted for publication including all changes made as a result of the peer review process, and which may also include the addition to the article by IOP Publishing of a header, an article ID, a cover sheet and/or an 'Accepted

Manuscript' watermark, but excluding any other editing, typesetting or other changes made by IOP Publishing and/or its licensors"

This Accepted Manuscript is @ 2020 IOP Publishing Ltd.

During the embargo period (the 12 month period from the publication of the Version of Record of this article), the Accepted Manuscript is fully protected by copyright and cannot be reused or reposted elsewhere.

As the Version of Record of this article is going to be / has been published on a subscription basis, this Accepted Manuscript is available for reuse under a CC BY-NC-ND 3.0 licence after the 12 month embargo period.

After the embargo period, everyone is permitted to use copy and redistribute this article for non-commercial purposes only, provided that they adhere to all the terms of the licence https://creativecommons.org/licences/by-nc-nd/3.0

Although reasonable endeavours have been taken to obtain all necessary permissions from third parties to include their copyrighted content within this article, their full citation and copyright line may not be present in this Accepted Manuscript version. Before using any content from this article, please refer to the Version of Record on IOPscience once published for full citation and copyright details, as permissions will likely be required. All third party content is fully copyright protected, unless specifically stated otherwise in the figure caption in the Version of Record.

View the article online for updates and enhancements. 


\title{
Study of Biomorphic Calcium Deficient Hydroxyapatite Fibres derived from a Natural Harakeke (Phormium Tenax) Leaf Fibre Template
}

\author{
Humair A. Siddiqui ${ }^{1,2}$, Kim L. Pickering ${ }^{1}$ and Michael R. Mucalo ${ }^{3}, *$ \\ ${ }^{1}$ School of Engineering, University of Waikato, Hamilton 3240, New Zealand; ahumair@hotmail.com; klp@waikato.ac,nz \\ ${ }^{2}$ Department of Materials Engineering, Faculty of Chemical \& Process Engineering, NED University of Engineering \& Technology, \\ Karachi 75270, Pakistan \\ ${ }^{3}$ School of Science, University of Waikato, Hamilton 3240, New Zealand \\ * Correspondence: michael.mucalo@waikato.ac.nz
}

Received xxxxxx

Accepted for publication $\mathrm{xxxxxx}$

Published xxxxxx

\begin{abstract}
The complex structure of natural bio-organic matter has inspired scientists to utilise these as templates to design "biomorphic materials", which retain the intricate architecture of the materials while acting as a useful bioactive material. Biomorphic hydroxyapatite-based fibres were synthesised using Harakeke leaf fibre as a template, which constitutes a powerful method for manufacturing bioactive ceramic fibres. Furthermore, in creating the hydroxyapatite-based fibres, a natural source of calcium and phosphate ions (from bovine bone) was utilised to create the digest solution in which the leaf fibres were immersed prior to their calcination to form the inorganic fibres. Chemical, thermogravimetric and microscopic characterisation confirmed that the final product was able to successfully replicate the shape of the fibres and furthermore be transformed into calcium deficient, bone-like hydroxyapatite.
\end{abstract}

Keywords: Hydroxyapatite, Biomorphic, Harakeke/Flax, Fibres, Bioceramic, Bovine Bone Repurposing

\section{Introduction}

The research in the field of "Biomimetic materials" has led to the development of various useful materials having a design motif of naturally produced materials. A variety of multifunctional materials especially biomorphic ceramics have been developed using several biotemplating techniques [1-3]. The development process of a biomorphic ceramic is relatively simple and effective, as ceramics easily inherit microstructural features of natural materials without too much modification. Ceramic materials composed of $\mathrm{Al}_{2} \mathrm{O}_{3}, \mathrm{SiC}$, $\mathrm{TiO}_{2}$ and $\mathrm{ZrO}_{2}$ have been trialled for forming structures (like fibres, porous structures, coatings) using the biotemplating techniques, for e.g. Dong et. al. [4] utilized eggshell membrane (ESM) as a biotemplate and an aqueous soaking technique to synthesize biomorphic mesoporous $\mathrm{TiO}_{2}$ with an interwoven meshwork formation. These biomorphic ceramics were found to be suitable for applications like heat insulation, electrical capacitors and membranes for sensors [5-8]. One significant use of biomorphic ceramics is as a biomedical material. González et al. [9] developed bioactive glass-coated biomorphic $\mathrm{SiC}$ thin films that were found to possess low density, bio-inertness well structures with interconnected porosity and improved mechanical properties. They proposed this material as an alternative to titanium and titanium alloy for medical purposes. Similarly, Rambo et al. [10] developed biomorphic alumina sponges coated with bioactive calcium phosphate layers for biomedical applications. Recent developments in bone tissue engineering revealed the importance of porous scaffolds as an effective approach to promote the repair and regeneration of diseased or damaged bone tissue. An ideal porous scaffold is required to possess excellent bioactivity, osteoconductivity, controlled biodegradability, reasonable mechanical strength and a network of interconnected porosity to serve as a template for bone ingrowth, [11-13].

Porous hydroxyapatite $\left(\mathrm{Ca}_{10}\left(\mathrm{PO}_{4}\right)_{6}(\mathrm{OH})_{2}\right.$, HAp) ceramics mostly fulfil the criteria required for ideal implant material, although an obvious and classical problem has been the poor mechanical properties that the material has[14, 15]. A number of studies has reported the formation of a bone-like apatite layer on porous HAp material surfaces in vitro and stimulation of new bone formation and growth into the interconnected porosity of a scaffold/implant [16-18]. To synthesise HAp with a natural porous network and to imitate the porous 
structure of spongy bone, scientists have tried different techniques such as polymeric sponge replication [19], animal bone conversion [20], electrospinning [21], phase-separation [22], freeze-drying [23], and gel-casting techniques [24], however templated synthesis of hydroxyapatite based materials have attracted considerable interest in the last 10 years[25-27]. Research on apatitic ("hydroxyapatite"-like) mineralisation from super-saturated calcium phosphate solutions has led to the view that amorphous calcium phosphate (ACP) is a precursor phase of crystalline hydroxyapatite i.e. it is the initial solid that emerges (precipitated) from a super-saturated calcium and phosphate ion-containing solution. However, due to its unstable nature (mainly due to its disordered structure) it readily phasetransforms into the thermodynamically more stable crystalline apatitic phase[28-31]. Although, the exact formation mechanism of ACP is still debatable, there have been some theories proposed for it. One such theory, presented by Posner and Betts[32] proposes the formation of pre-nucleation clusters known as "Posner's cluster", which constitute approx. $1 \mathrm{~nm}$ size clusters of $\mathrm{Ca}_{9}\left(\mathrm{PO}_{4}\right)_{6}$. Experimental studies by Onuma \& Ito [33] and Wang et al. [34] have also proposed the existence of such nanometre sized clusters prior to ACP formation. Another theory proposed by others suggests that the formation of pre-nucleation clusters of calcium tri(hydrogenphosphate) $\quad\left[\mathrm{Ca}\left(\mathrm{HPO}_{4}\right)_{3}\right]^{4-}$ ion-associated complexes of similar sizes to be the building blocks of ACP [35]. ACP has a chemical composition of $\mathrm{Ca}_{9}\left(\mathrm{PO}_{4}\right)_{6}$ with a $\mathrm{Ca} / \mathrm{P}$ mole ratio of approx. 1.5 and is considered a random assembly of ion clusters (for which diffraction studies have proven to possess short range ordering). ACP particles usually have sizes in the range of 300-1000 $\AA$, but their exact size depends on the preparation conditions used. It is understood that there water molecules residing in the interstices between, and not within, the individual clusters to an extent of $15-20 \%$ [36]. It is also believed HAp embryos from ACP form, upon the rearrangement of calcium and phosphate ions in ACP that occurs after an exchange of ions with the surrounding solution takes place. Once such embryos reach a critical size, then crystallinity gradually increases. However, some studies also report formation of intermediate phases (like octacalcium phosphate (OCP)) during the conversion [37].

One of the most important criteria for any template-assisted synthesis of HAp is the selection of a suitable template and its possible contribution to the apatitic mineralisation. In terms of using natural templating materials for making bio-inspired materials, research workers in the last 20 years have utilised many natural biological materials like soft- and hardwoods, silk, cotton, coral and coir fibres to synthesise different ceramic materials. The microstructure produced, retains the natural biological features and uniformity of the template used. Wood is a natural biopolymeric composite composed of hemicellulose, cellulose and lignin. It displays a complex macro/micro/nano-structure with ordered cellular honeycomb-like channels, which resembles the structure of cancellous bone[5, 7]. One study reported the successful use of heat-treated birch wood directly as an implant for osteochondral bone defects in a rabbit [38]. Many different types of wood (or wood-derived materials) due to their open trabecular structure, have been used as templates for making porous ceramics providing flexibility for the manufacture of complex shapes, biological properties, and inherent 3D interconnected porous structure. Harakeke (Phormium tenax, New Zealand flax) is a unique and ancient plant species, which is monocotyledonous. This plant usually has long stiff/erect leaves, which can grow up to $3 \mathrm{~m}$. When exploring the anatomy of leaves, the aggregates of fibres, referred to as muka (from the Māori language), can be found lying along the leaf, which are extractable sclerenchyma fibres (individual elongated hollow cells). This plant was very popular with European traders due to the extraordinary strength of its muka. They called it 'flax' because its fibres were like that of true flax found in other parts of the world. Clothing, mats, plates, baskets, ropes, fishing lines and nets were all made from the flax leaves by Māori. [39, 40]. Like every lignocellulosic fibres, Harakeke also consist of three main components: cellulose, lignin, and water. A typical chemical composition of Harakeke is presented in Table 1. The cellulose and lignin are usually tightly bound together, while the water is adsorbed on the cellulose/lignin structure.

Table 1: Chemical composition of Harakeke fibre as reported in literature [41]

\begin{tabular}{|l|l|}
\hline Composition & Percentage \\
\hline Cellulose & 45.1 \\
\hline Hemicelluloses & 30.1 \\
\hline Pectin & 0.7 \\
\hline Lignin & 11.2 \\
\hline Water solubles & 2.2 \\
\hline Fat and wax & 0.7 \\
\hline Moisture & 10 \\
\hline
\end{tabular}

Harakeke fibres like other lignocellulosic fibres have multi layered cell wall structures which can be categorised into three major layers, middle lamella (the most outer layer, composed of "pectins" (heterogeneous polysaccharides), which helps in cell binding/adhesion), primary cell wall (composed of polysaccharides cellulose, hemicellulose, and pectin), and secondary cell walls (composed of cellulose and hemicellulose, however sometime they also contain lignin, which is a complex polymer of aromatic aldehydes). Lumen in fibre is a narrow central channel formed when a plant cell dies at the end of biosynthesis [42, 43]. A typical cell wall structure in natural fibre is presented in Figure 1. Harakeke fibres are generally regarded as highly porous, due to a large lumen and are hydrophilic in nature. Their surface chemistry is determined by the presence of reactive hydroxyl groups - 
$\mathrm{OH}$ which mainly emanate from cellulose. Carboxyl groups $\mathrm{COOH}$ are also found at the surface due to pectins, hemicelluloses and fatty acids, however their contribution to the surface chemistry is still unknown[44, 45]. Moreover, Harakeke fibres can also potentially have small amounts of aldehydes - $\mathrm{COH}$ and esters - COOR due to lipophilic components (aldehydes, sterol esters and ester waxes), however this has not been confirmed in studies to date.

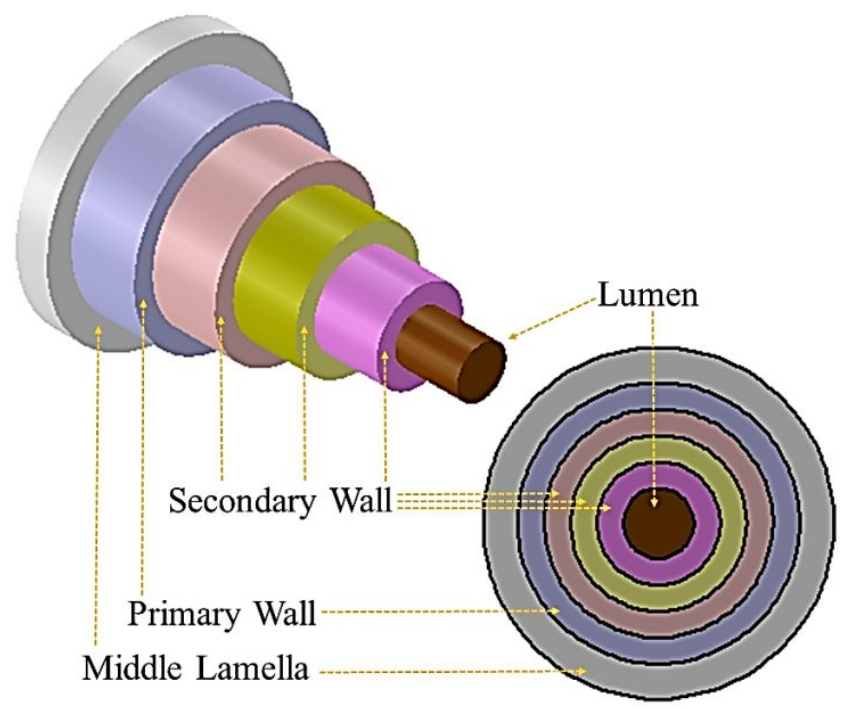

Figure 1. Cell wall structure of Harakeke fibre.

In the present study, we have trialled combining the techniques of biotemplating and HAp re-precipitation processing for the first time on Harakeke fibres, to develop novel biomorphic HAp ceramic materials.

\section{Materials and Methods}

\subsection{Materials}

All chemicals and solvents used in the experimental work were employed in as-received condition, without further purification. Nitric acid $\left(\mathrm{HNO}_{3}\right)(65 \%$, Merck Germany) was used to carry out digestions. The natural mechanically stripped Harakeke (Phormium tenax) leaf fibres (supplied by Foxton Flax Stripping Museum, NZ) were used as the biotemplate. Ultra-pure water (Type 1) was used for all experimental and cleaning purposes. Raw sectioned bovine femur bones (in frozen condition, breed unknown) were used as a source of calcium and phosphate ions and were purchased from the butcher's section of a major supermarket chain in New Zealand. The pre-sectioned frozen bones/were defrosted in water at room temperature for 24 hours before defatting was carried out.

\subsection{Solution preparation}

The first step for developing biomorphic HAp fibres is the making of a solution containing $\mathrm{Ca}^{2+}$ and $\mathrm{PO}_{4}{ }^{3-}$ ions. This solution was produced from bovine femur bone, which was processed to remove most of the unwanted, extraneous organic matter. The cleaning (defatting) process involved boiling of the raw bones for 8 hours with a change of water after every 2 hours followed by drying at $105^{\circ} \mathrm{C}$ for 12 hours in an oven. Defatted and dried bones were subjected subsequently to heat treatment at $1000{ }^{\circ} \mathrm{C}$ for 4 hours. This temperature $\left(1000{ }^{\circ} \mathrm{C}\right)$ was chosen after performing a thermogravimetric analysis of the defatted bone. The heat treatment was designed in a way to ensure that removal of all organic matter namely collagenous protein and carbonate occurs such that crystalline hydroxyapatite is achieved/precipitated. The bone obtained after heat treatment was white in colour and fragile in nature. These bones are referred to as "sintered cow bone" in this paper. After this heating process, sintered cow bones were crushed to obtain powder which was subsequently digested in dilute $(20 \%)$ nitric acid. This solution is referred to as "digest solution". The $\mathrm{pH}$ of $20 \%$ nitric acid solution and digest solution was found to be -0.03 and -0.01 respectively. The initial concentration of $\mathrm{Ca}^{2+}$ and $\mathrm{PO}_{4}{ }^{3-}$ ions in the digest solution was experimentally found (using ICP-MS and analysed as $\mathrm{Ca}$ and $\mathrm{P}$ ) to be approx. $331,232 \mathrm{ug} / \mathrm{L}$ and 178,262 ug/L respectively.

\subsection{Harakeke leaf fibre formation and initial treatments}

The natural Harakeke (Phormium tenax) leaf fibres were treated with $0.5 \mathrm{M} \mathrm{NaOH}$ solution for 2 hours at room temperature (to increase surface roughness and/or wettability), thoroughly washed with water and then dried overnight at 60 ${ }^{\circ} \mathrm{C}$. The dried and loose alkali-treated Harakeke leaf fibres were then immersed in the digest solution for 24 hours (solid to liquid ratio $1: 10$ ) to allow infiltration of the inorganic ions. The left over digest was found to be brownish in colour and had a $\mathrm{pH}$ of approx. 0 . After drying at $60{ }^{\circ} \mathrm{C}$ for 8 hours, the fibres were then oxidised at $1000^{\circ} \mathrm{C}$ for 3 hours in an alumina crucible. This results in the formation of long entangled white fibres, which may have ash content due to burning of plant fibres. These fibres are referred to as "biomorphic fibres (as formed)" in this paper. A sample of "biomorphic fibres (as formed)" was taken for additional analysis by Fourier transform infrared (FTIR) and powder X-ray diffraction (XRD) only. The resultant long entangled fibres were subsequently subjected to $0.1 \mathrm{M} \mathrm{NaOH}$ solution washing treatment for 10 minutes to remove ash content. A pictorial representation of the process steps is represented in Figure 2. The short fibres; namely "biomorphic fibres (final product)"; obtained were then subjected to chemical, thermogravimetric and microscopic characterisation.

\subsection{Characterisation}

An FTIR spectrometer (Spectrum 100A Express, Perkin Elmer) was utilised for recording IR spectra of the Harakeke fibres, sintered cow bone and biomorphic fibres (both as 
formed and final product), via the potassium bromide ( $\mathrm{KBr})$ disc method (spectra were recorded between $4000-450 \mathrm{~cm}$ 1). A spectral resolution of $4 \mathrm{~cm}^{-1}$ was used. Raman spectra of biomorphic fibres (final product) were recorded with a Raman station 400F (Perkin Elmer) spectrometer with a spectral resolution of $1 \mathrm{~cm}^{-1}$ (laser $785 \mathrm{~nm}$ near-infrared laser). Thermogravimetric analysis (TGA) (STA 8000, Perkin Elmer) was also carried out to study the loss of weight associated with the different heating events of the raw and digest solution-treated fibres. Thermograms were recorded from room temperature to $800{ }^{\circ} \mathrm{C}$ in an air atmosphere. The thermogram of the imbibed fibres provides information on the formation of the biomorphic fibres from the Harakeke fibres imbibed with digest solution. The phase composition of biomorphic fibres (final product) was determined by X-ray diffractometry (Panalytical Empyrean Series 2 diffractometer) with $\mathrm{Cu} \mathrm{K} \alpha$ radiation at $45 \mathrm{kV} \& 40 \mathrm{~mA}(\lambda=1.5406 \AA)$ and step size of $0.0260^{\circ}$. An XRD study of raw Harakeke and digest treated-fibres heated at various temperatures was performed to understand the biomorphic formation of HAp. The elemental analysis of sintered cow bone, biomorphic fibres (as formed and final product) was done using an inductively coupled plasma mass spectrometer (ICP-MS, Agilent 8900 triple quadrupole (QQQ)). A sample of biomorphic fibres (final product) was also tested for elemental analysis, through an external analytical company (Analytica Ltd, Hamilton, New Zealand) to verify the $\mathrm{Ca} / \mathrm{P}$ mole ratio value. The morphological characteristics of the samples were recorded using a scanning electron microscope (SEM) (S4700 , Hitachi) instrument in the form of fibres placed on an aluminium stub using high purity conductive double sided adhesive carbon tape. Prior to imaging, all samples were sputter coated with platinum to avoid surface charging issues.

\section{Results \& Discussion}

\subsection{FTIR Analysis}

The chemical structure of Harakeke fibres (raw and alkalinetreated) were analysed using FTIR, as it is an appropriate technique for observing any changes introduced in the chemical structure of natural fibres due to the different treatments. The main IR absorbance peaks of interest have been identified and are shown for comparison in Figure 3. Upon comparison of both spectra, no visible change was found in the bands at 2922 and $2855 \mathrm{~cm}^{-1}$, which are usually attributed to the $\mathrm{C}-\mathrm{H}$ stretching modes in cellulose, however a very small change in the intensity of the two characteristic lignin bands at 1508 and $1596 \mathrm{~cm}^{-1}$ (which relate to the aromatic skeletal vibrations of lignin) and the band at 1461 $\mathrm{cm}^{-1}$ (attributed to the $\mathrm{C}-\mathrm{H}$ deformations in lignin), was found and hence it is plausible to assume that a very small and negligible amount of lignin was removed due to the mild alkali treatment. There was found to be a considerable change in the intensity of the carbonyl band $(>\mathrm{C}=\mathrm{O})$ at $1734 \mathrm{~cm}^{-1}$, which is a signature peak of hemicellulose. Similarly, the decrease in the intensity of the peak at approx. $1250 \mathrm{~cm}^{-1}$ (stretching vibration of the $\mathrm{C}-\mathrm{O}$ single bond) suggests the partial removal of hemicelluloses in the treated fibres. The peak at around $1638 \mathrm{~cm}^{-1}$ is principally associated with adsorbed water. The prominent band at around $1052 \mathrm{~cm}^{-1}$ is attributed to the $\mathrm{C}-\mathrm{O}$, $\mathrm{C}-\mathrm{C}$ stretching and $\mathrm{C}-\mathrm{OH}$ stretching vibrations in hemicellulose, cellulose and lignin. The sharp band at around $899 \mathrm{~cm}^{-1}$ is due to the $\beta$-glycosidic bond, and is also representative of the occurrence of the crystalline phase of cellulose type I. The bands at 1461, 1381, 1328 and $1250 \mathrm{~cm}^{-}$ ${ }^{1}$ represent $\mathrm{C}-\mathrm{H}, \mathrm{OH}$ or $\mathrm{CH}_{2}$ bending [46-49].

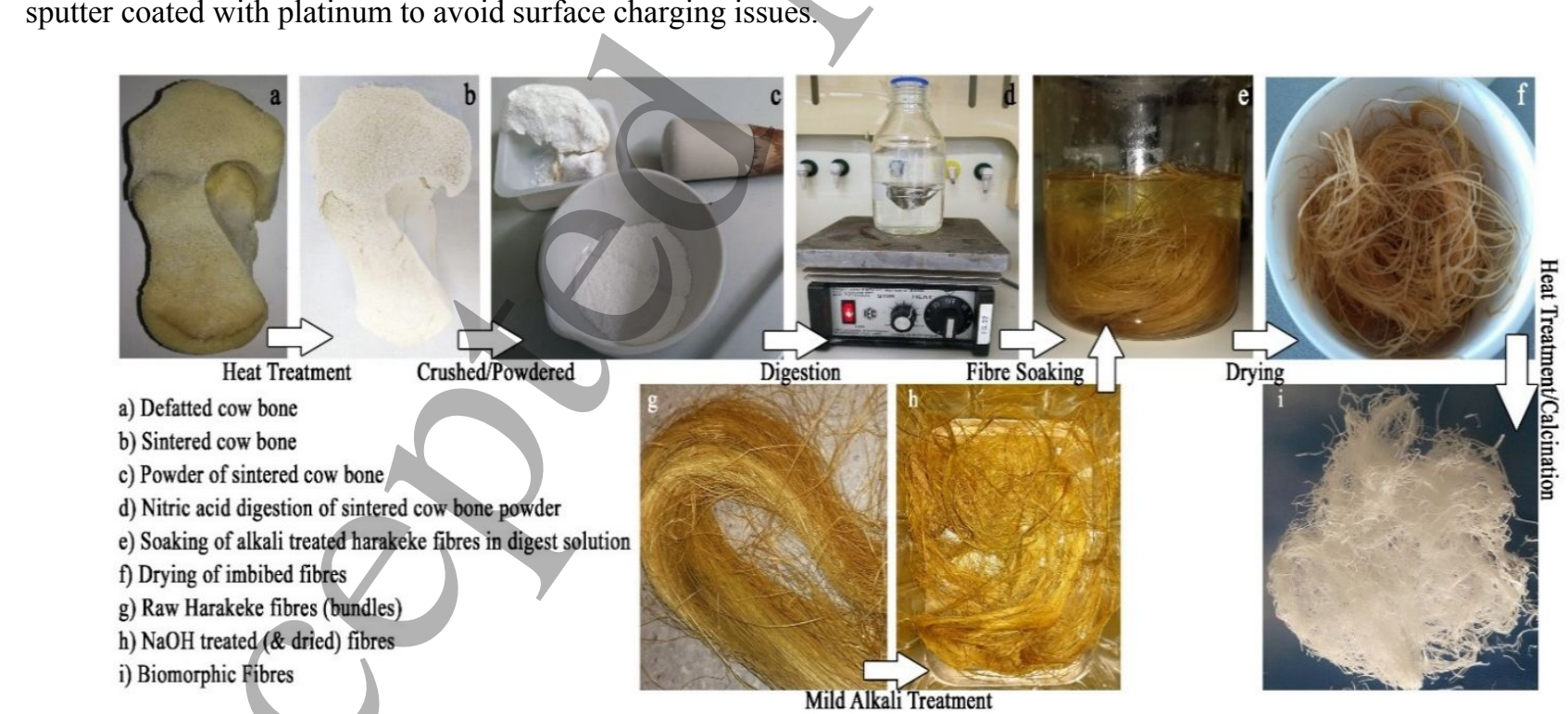

Figure 2. A pictorial representation of the processing steps, which summarises production of the digest solution containing calcium and phosphate ions and the soaking and calcination of the $\mathrm{NaOH}$ treated Harakeke fibres in the solution, resulting in the production of the biomorphic fibres. 


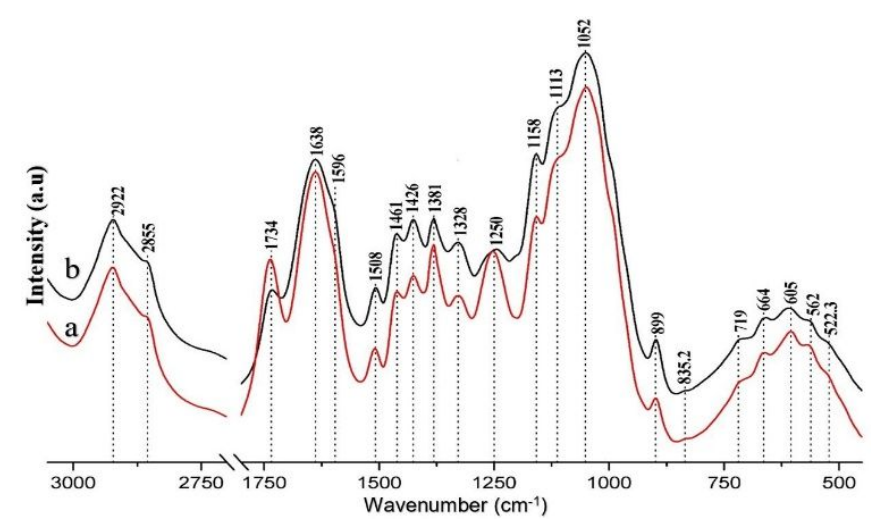

Figure 3. FTIR spectra of (a) raw Harakeke fibres, and (b) mild alkaline treated Harakeke fibres. Spectra were recorded as pressed $\mathrm{KBr}$ discs.

FTIR analysis was also carried out on sintered cow bone, Figure 4 (a), to confirm HAp had been prepared, as well as to ensure that during sintering complete deproteinisation had taken place. The complete deproteinisation is important to avoid xanthoproteic-associated reactions that can result in impurities and discolouration during its digestion in nitric acid[50]. The IR spectra of sintered cow bone depicts all the characteristic peaks of the HAp lattice, which include peaks related to $\mathrm{PO}_{4}{ }^{3-}$, hydroxyl modes and $\mathrm{CH}_{\mathrm{n}}$ stretching vibrations [20, 51-55]. The small peak at around $1385 \mathrm{~cm}^{-1}$ which appeared in all the spectra is most likely due to a nitrate impurity which would have emanated from the nitric acid used to form the digest solution. Hence it can be deduced that at $1000{ }^{\circ} \mathrm{C}$, crystalline hydroxyapatite has been produced from raw cow bone after complete deproteinisation.

The FTIR analysis of the biomorphic fibres (both as formed and final product) was carried out to monitor for the formation of HAp in the fibres, as well as to assess qualitatively their crystallinity. Figure 4 (b), which represents the spectra of biomorphic fibres (as formed), shows the characteristic peaks of stoichiometric hydroxyapatite. The band centred around $1000-1100 \mathrm{~cm}^{-1}$ is the main peak confirming the formation of hydroxyapatite. The peaks at around $961.6 \mathrm{~cm}^{-1}$ and $602 \mathrm{~cm}^{-1}$ are related to the $v_{1}$ and $v_{4}$ fundamental vibrational modes of the phosphate group [20, 51-55]. The bands at around 875,1414 and $1458 \mathrm{~cm}^{-1}$ indicate the presence of the $\mathrm{CO}_{3}{ }^{2-}$ group (type-B i.e. $\mathrm{CO}_{3}{ }^{2-}$ substituting for $\mathrm{PO}_{4}{ }^{3-}$ ) however it is generally obseryed that $\sim 1465, \sim 1413$, and $\sim 873 \mathrm{~cm}^{-1}$ are characteristic bands for type-B substitution. The missing band at approx. $1465 \mathrm{~cm}^{-1}$ point towards the possibility of labile (free) carbonate being present rather than substituted carbonate, as carbonate in HAp can either be substituted in the lattice or labile (labile meaning adsorbed on its surface or present by association as a separate entity/compound). Studies by Ren and Leng[55] and Ren, Ding and Leng [54] showed that along with the different bands of carbonate, the presence of a specific band (which they termed the "signature band") is essential to deduce whether there is substitution of $\mathrm{CO}_{3}{ }^{2-}$ in the lattice. If that specific band is absent, the carbonate can be considered labile rather than substituted. They found out that the signature band for type-B $\left(\mathrm{CO}_{3}{ }^{2-}\right.$ substituting for $\left.\mathrm{PO}_{4}{ }^{3-}\right)$ is at $\sim 1465 \mathrm{~cm}^{-1}$. Hence in the case of biomorphic fibres (as formed) the absence of the $\sim 1465 \mathrm{~cm}^{-1}$ signature band indicate that the carbonate identified in the IR spectrum is labile in nature, most probably adsorbed on the surface (due to highly porous nature of fibres) during cooling in the furnace. Moreover, a new peak at around $1617 \mathrm{~cm}^{-1}$ might be adsorbed $\mathrm{CO}_{2}$, in line with the previous studies based on the adsorption of $\mathrm{CO}_{2}$ on the HAp surface[56, 57], where the appearance of different bands in the range of $1600-1700 \mathrm{~cm}^{-1}$ were reported after the successful adsorption of $\mathrm{CO}_{2}$ on the HAp surface. The band in the range of 3250$3700 \mathrm{~cm}^{-1}$ and the peak at around $1633 \mathrm{~cm}^{-1}$ is due to adsorbed $\mathrm{H}_{2} \mathrm{O}$ /moisture[58]. This was found to be increased in the biomorphic fibres (as formed) from sintered cow bone (Figure 4(a)) and is most likely the result of the fibres' extensive porous network that will be favourable for adsorbing water from the ambient air. The band at $3573 \mathrm{~cm}^{-1}$ is due to the $\mathrm{O}-\mathrm{H}$ stretching modes of lattice HAp hydroxyl groups, which shows the presence of hydroxyapatite. Comparison of the IR spectra of biomorphic fibres (as formed) with the biomorphic fibres (final product), (Figure 4(c)), reveals the effect of $\mathrm{NaOH}$ washing treatment on fibres. All the characteristic peaks of HAp remained unaltered, however there was found to be an increase in the intensities of bands due to adsorbed (labile) carbonate (at 875,1414 and $1458 \mathrm{~cm}^{-1}$ ). This would have resulted from the formation of a small amount of free calcium carbonate (confirmed from XRD) that would normally accompany any exposure to an alkaline solution under ambient conditions. Moreover, an increase in the band intensity of adsorbed water (3442 and $1633 \mathrm{~cm}^{-1}$ ) was also noted, which indicates the increased uptake of water during washing treatment. Table 2 enlists all the identified peaks of biofibre (as formed and final product). In general, the IR readily confirms the formation of crystalline HAp in the form of fibres via the aqueous soaking and sintering technique. 


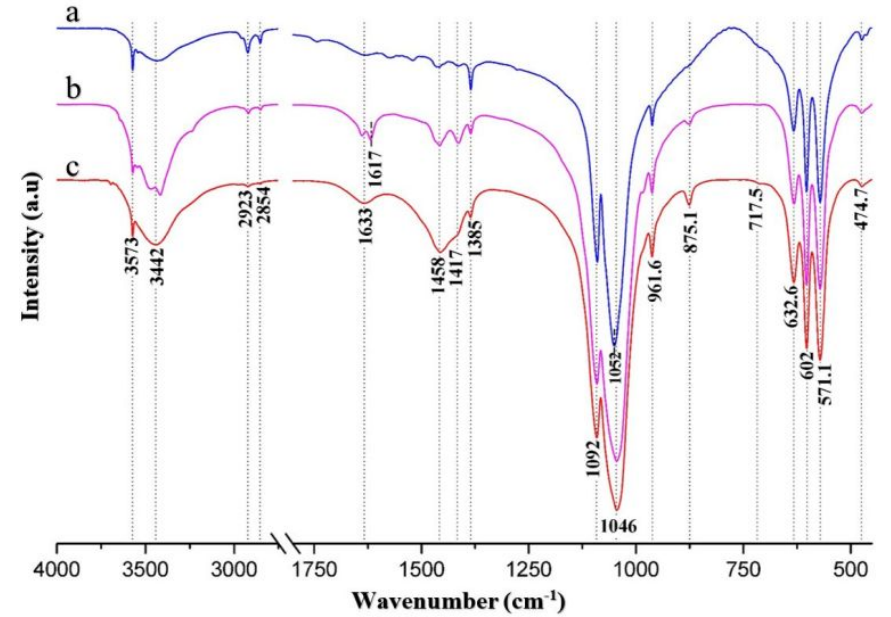

Figure 4. FTIR spectrum of (a) sintered cow bone (b) Biomorphic fibres (as formed) (c) Biomorphic fibres (final product)

Table 2: Assignment of the FTIR spectra of the calcium phosphate samples acquired in this study

\begin{tabular}{|c|c|c|}
\hline Vibration Band & $\begin{array}{l}\text { Biomorphic } \\
\text { Fibres } \\
\text { (As formed) }\end{array}$ & $\begin{array}{l}\text { Biomorphic } \\
\text { Fibres } \\
\text { (final } \\
\text { product) }\end{array}$ \\
\hline $\mathrm{PO}_{4}^{3-}\left(\mathrm{O}_{2}\right)$ bending mode & 474.4 & 474.4 \\
\hline $\mathrm{PO}_{4}{ }^{3-}\left(\mathrm{v}_{4}\right)$ asymm. bending mode & 571.1 & 571.1 \\
\hline $\mathrm{PO}_{4}^{3-}\left(\mathrm{v}_{4}\right)$ asymm. bending mode & 602 & 602 \\
\hline OH libration & 632.6 & 632.6 \\
\hline $\begin{array}{l}\mathrm{P} \mathrm{P} \mathrm{Q}^{3}, \mathrm{Q}^{2} \text { and } \mathrm{Q}^{1} \text { units symm. } \\
\text { stretching }\end{array}$ & 717.5 & 717.5 \\
\hline $\begin{array}{l}\mathrm{HPO}_{4}{ }^{2-} \text { ions vibrations } \\
\mathrm{CO}_{3}{ }^{2-}\left(\mathrm{v}_{2}\right) \text { asymm. bending mode }\end{array}$ & 875.1 & 875.1 \\
\hline $\mathrm{PO}_{4}^{3-}\left(v_{1}\right)$ symm. stretching mode & 961.6 & 961.6 \\
\hline $\mathrm{PO}_{4}^{3-}\left(\mathrm{v}_{3}\right)$ asymm. stretching mode & $1043-1092$ & $1043-1092$ \\
\hline Nitrate impurity (from nitric acid used) & 1385 & 1385 \\
\hline $\begin{array}{l}\mathrm{CO}_{3}^{2-}\left(\mathrm{v}_{3}\right) \text { asymm. } \\
\mathrm{C}-\mathrm{O} \text { stretching mode }\end{array}$ & $\begin{array}{l}1417 \\
1458\end{array}$ & $\begin{array}{l}1417 \\
1458\end{array}$ \\
\hline Adsorbed $\mathrm{CO}_{2}$ & 1617 & -- \\
\hline $\mathrm{H}-\mathrm{O}-\mathrm{H}\left(\mathrm{v}_{2}\right)$ bending mode & 1633 & 1633 \\
\hline $\begin{array}{l}\mathrm{sp}^{3}-\text { and } \mathrm{sp}^{2}-\text { hybridized } \mathrm{CH}_{\mathrm{n}} \text { stretching } \\
\text { vibrations }\end{array}$ & 2923,2854 & 2923,2854 \\
\hline $\begin{array}{l}v_{1} \text { and } v_{3} \text { stretching modes of hydrogen- } \\
\text { bonded } \mathrm{H}_{2} \mathrm{O} \text { molecules }\end{array}$ & $3250-3700$ & $3250-3700$ \\
\hline
\end{tabular}

Results obtained from FTIR were also used to calculate the crystallinity index $(\mathrm{CI})$, which is generally defined as the measure of fraction of crystallinity of one phase in a given sample. The CI helps in accessing the extent of splitting in the $\mathrm{PO}_{4}^{3-}$ band (which actually reflects increase in crystallinity) and is defined by $[59,60]$ :

$$
\begin{gathered}
C I=\frac{A_{x}+A_{y}}{A_{z}} \text { [or as per notation in Figure } 5, C I= \\
\left.\frac{A A^{\prime}+C C^{\prime}}{B B^{\prime}}\right] \text { (eq. 1) }
\end{gathered}
$$

where, $A_{x}, A_{y}$ and $A_{z}$, represent the absorbance values at wavenumber $\mathrm{x}, \mathrm{y}$ and $\mathrm{z}$, respectively which in the present study are defined to be 602,571 and $590 \mathrm{~cm}^{-1}$. However, in carrying out this calculation using absorbance intensities the relevant portion of the IR spectrum (like in the case of the biomorphic fibres, $750-450 \mathrm{~cm}^{-1}$ ) needs to be baseline corrected (see Figure 5). The heights of the $602 \mathrm{~cm}^{-1}$ and 571 $\mathrm{cm}^{-1}$ absorptions are summed and then divided by the height of the valley between them. Crystallinity indices (CI) of the biomorphic fibres (final product) was found to be 4.60.

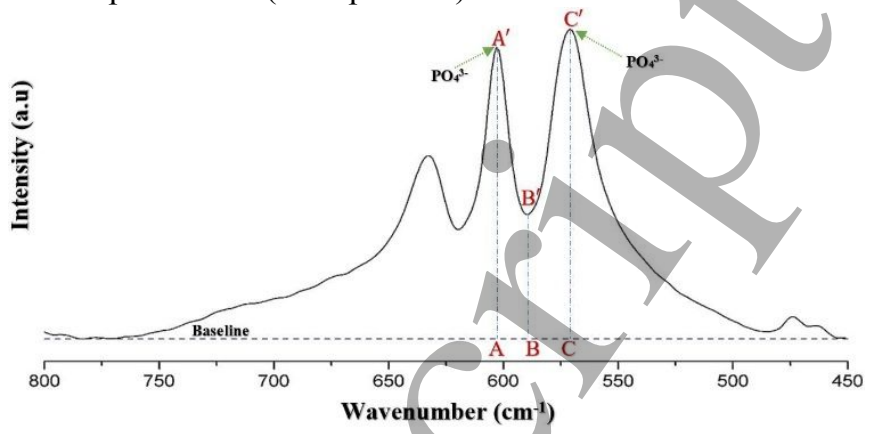

Figure 5. Portion of the IR spectrum of biomorphic fibres (final product) used to calculate CI.

\subsection{Raman Spectroscopy Analysis}

Raman spectroscopy, which has been used to complement results obtained through IR spectroscopy, can also be used to calculate crystallinity index (CI). The Raman spectrum of biomorphic fibres (final product) displayed the characteristically strong $\mathrm{PO}_{4} \mathrm{v}_{1}$ peak at around $962 \mathrm{~cm}^{-1}$, which is the strongest signal in the Raman confirming the presence of hydroxyapatite (see Figure 6). Apart from this, peaks corresponding to the vibrational modes of phosphate groups, i.e. $v_{2}\left(\mathrm{PO}_{4}\right)$ at $431 \& 447.0 \mathrm{~cm}^{-1}, v_{3}\left(\mathrm{PO}_{4}\right)$ at 1076 , $1047,1041 \& 1028 \mathrm{~cm}^{-1}$ and $\mathrm{v}_{4}\left(\mathrm{PO}_{4}\right)$ at $615.6,607.5,591 \&$ $579.3 \mathrm{~cm}^{-1}$ peaks were also observed, which matches with available literature[61, 62].

Researchers have also used Raman spectral peaks to study crystallinity index, carbonate-to-phosphate ratio and mineral maturity of bone[63-67]. In this study, the crystallinity index (CI) from Raman spectra was calculated using the formula[68]:

$$
C I_{\text {Raman }}=F W H M_{962} \text { (eq. 2) }
$$

Where, $\mathrm{FWHM}_{962}$ is the full-width at half maximum of the peak representing the $-\mathrm{PO}_{4} \mathrm{~V}_{1}$ symmetric stretching mode at around $962 \mathrm{~cm}^{-1}$. The $\mathrm{CI}_{\text {Raman }}$ values represent the degree of atomic order, the larger the values, the wider is the peak and the more atomically disordered the material is [69]. The $\mathrm{CI}_{\text {Raman }}$ value of biomorphic fibres (final product) was found to be 5.528 . 


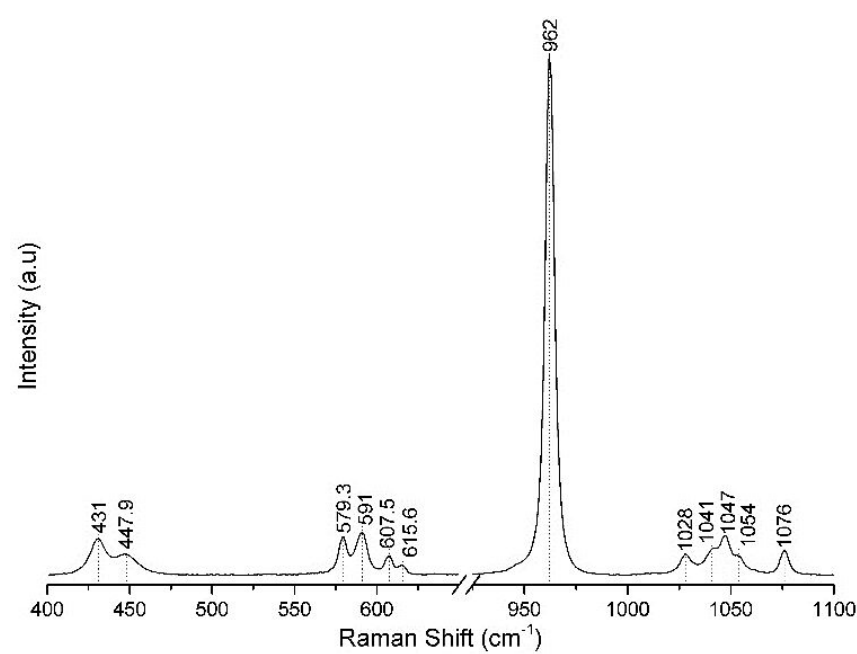

Figure 6. This figure represents the Raman spectrum of biomorphic Fibres (final product).

\subsection{Thermal Analysis}

Thermogravimetric analysis (TGA) of pre (raw Harakeke fibres) and post soaked fibres (digest solution-treated fibres) is a vital characterisation tool that helps in analysing processing steps which involve mass losses (mainly due to the combustion of cellulose, hemicellulose and lignin associated with the sample) and also helps in gaining insight into the eventual formation of the hydroxyapatite cast structure. Simultaneous differential scanning calorimetry (DSC) helps in detecting and correlating all the heat flow (either endothermic or exothermic) events occurring during degradation of the organic matrix and formation of HAp. Figure 7, shows the thermogram depicting weight loss curve and the corresponding heat flow curve of the raw Harakeke fibre bundles. Raw Harakeke fibres displayed an initial weight loss between 50 to $120^{\circ} \mathrm{C}$, mainly due to the removal of volatile content and free/adsorbed water in the fibres. It can be observed that the raw fibres did not show any noticeable thermal degradation below $200{ }^{\circ} \mathrm{C}$. More significant weight losses (up to approx. 90\%) were observed between $200^{\circ} \mathrm{C}$ and $500^{\circ} \mathrm{C}$. At the onset of $250^{\circ} \mathrm{C}$, fibres started to lose their weight mainly as a result of the thermal depolymerisation of hemicellulose and pectin, while the cellulose undergoes cleavage in its glycosidic linkages[70]. This stage was completed when the temperature reached approximately $350^{\circ} \mathrm{C}$ during which the fibres had lost almost $60 \%$ of their original mass. A broad exothermic peak can also be observed in the same temperature zone which supports the depolymerisation. The next and final stage of the thermal degradation occurred in the range of 400 to $500^{\circ} \mathrm{C}$ when the Harakeke had lost almost $97.5 \%$ of its initial weight leaving behind ash and residual minerals. The degradation of the $\alpha$ cellulose and lignin occurred during this stage $[45,71,72]$.

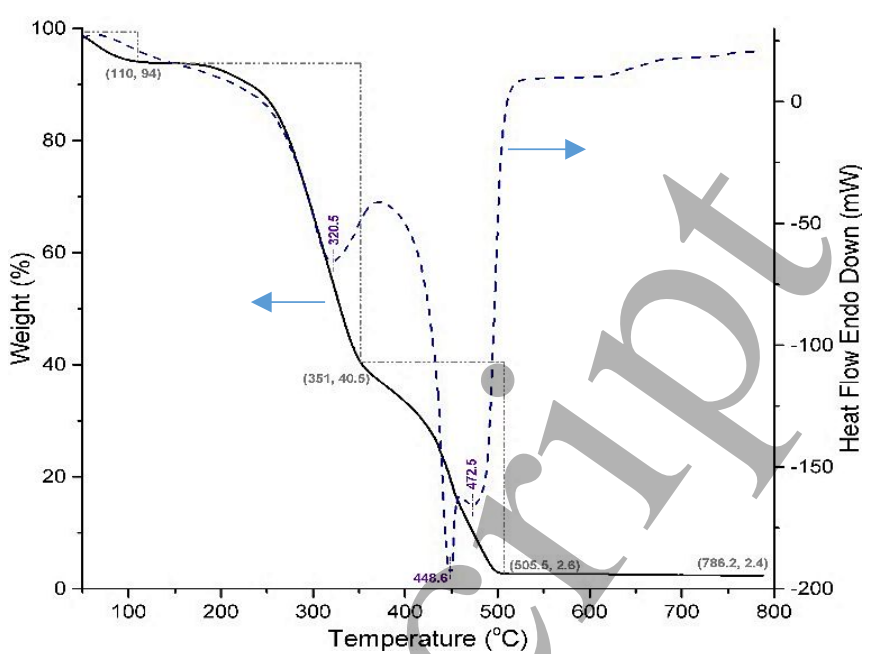

Figure 7. Thermogram (TGA-DSC) of raw Harakeke fibres, representing the degradation of its constituents.

While studying the associated thermogram of Harakeke fibres (Figure 8) that had previously been soaked/imbibed with the digest solution (apart from the initial weight loss due to the removal of free moisture and volatile content in the temperature range of $50-120^{\circ} \mathrm{C}$ ) three distinct stages were observed in comparison to the thermogram of the raw (untreated) fibres/ which showed contrastingly only two stages. Wang et al. [73] while developing a different biomorphic material i.e. $\mathrm{Al}_{2} \mathrm{O}_{3}$ using silk as a template and $\mathrm{AlCl}_{3}$ as an alumina source, also found an additional stage before burning/degradation of the silk template, which they referred to as the development of biomorphic alumina fibres. The thermogram in the present study depicts a stage in the temperature range of $140-200^{\circ} \mathrm{C}$, where approx. $20 \%$ of the weight was lost, which corresponds to the development of phases involving calcium and phosphate. The presence of the two exothermic peaks in the range of $140-200^{\circ} \mathrm{C}$ also supports this phase formation. After this, two broad peaks at around $330^{\circ} \mathrm{C}$ and $410^{\circ} \mathrm{C}$ were observed, which can be assigned to the depolymerisation of hemicellulose and degradation of cellulose respectively. On comparison of the area under the curve of associated peaks of hemicellulose, cellulose and lignin, it can be assumed that their content in the digest solution imbibed fibres was less in amount compared to the raw (unsoaked) fibres, which could be due to the presoaking in the highly acidic digest solution. The weight loss of approx. $3.5 \%$ from $500{ }^{\circ} \mathrm{C}$ to $800{ }^{\circ} \mathrm{C}$ could be due to the burning of char, which may have caused the initial formation of a protective layer of calcium phosphate on the fibres. An analysis of the weight loss curve shows a mass loss in the fibres of approx. $64 \%$ which indicates that the remaining $36 \%$ mass is due to biomorphic fibre and ash content. 


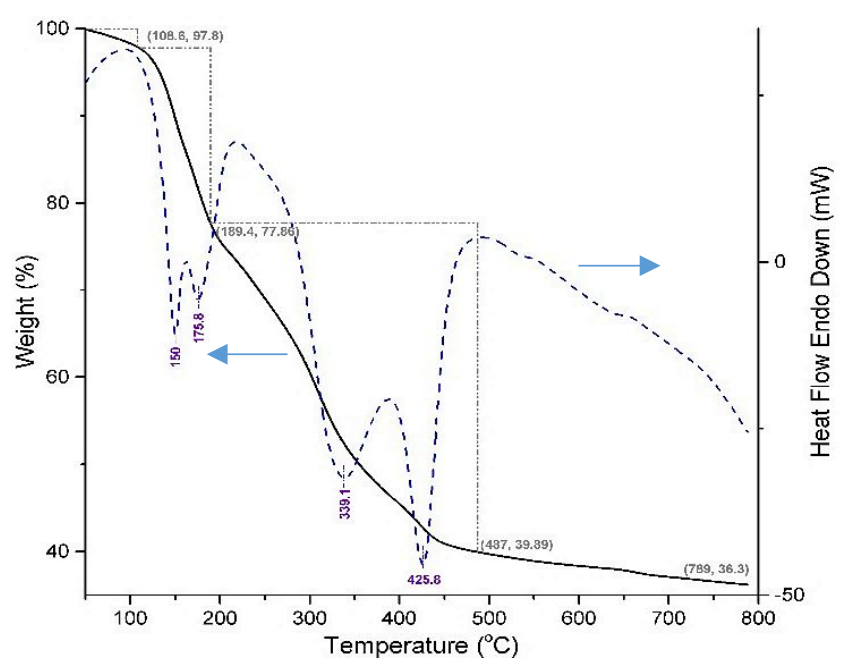

Figure 8. Thermogram (TGA-DSC) of solution-treated Harakeke fibres, representing the formation of HAp.

The derivative thermogravimetric analysis (DTG i.e. the first derivative of weight loss with respect to time) of both pre and post digest solution soaked fibres is presented in Figure 9. DTG curve of raw fibres clearly represent the major weight losses at around $300{ }^{\circ} \mathrm{C}$ and $450{ }^{\circ} \mathrm{C}$ as describe earlier, hence only a two-stage decomposition of raw fibres is evident, which is also found in other studies involving lignocellulosic-type fibres $[74,75]$. The DTG curve of soaked fibres also depicts an additional stage in the range of $140-200^{\circ} \mathrm{C}$ having two weight loss peaks. A minor hump at around $650^{\circ} \mathrm{C}$ can be associated with the either the burning of char or the degradation of the carbonate moiety which would have been introduced during the alkali treatment done to the increase in roughness/wettability of the fibres (Figure 2).

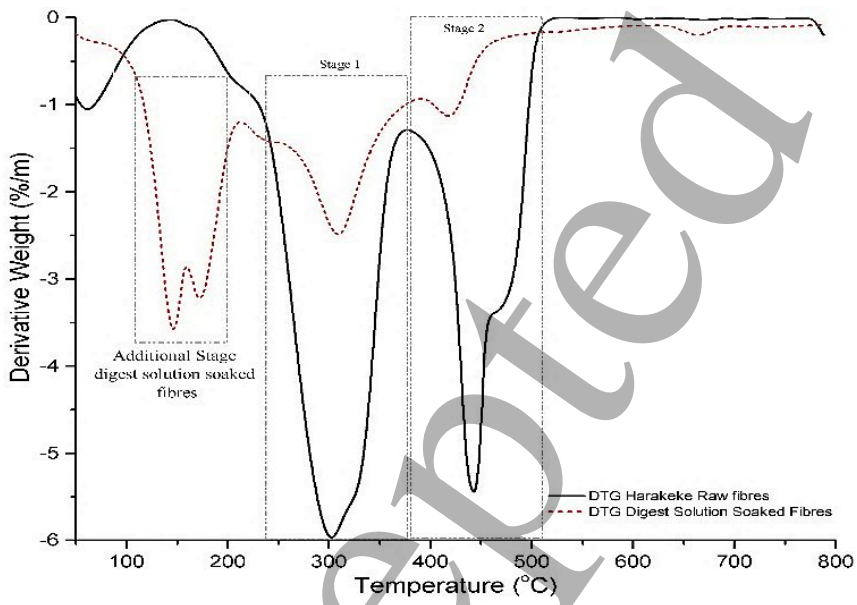

Figure 9. Derivative weight loss of raw and solution-treated Harakeke fibres.

\subsection{X-ray diffraction analysis}

Phase identification of biomorphic fibres (final product) was carried out via powder X-ray diffraction analysis. Figure 10 shows the XRD pattern of biomorphic fibres (final product) compared with the reference pattern from the database. The obtained spectra were imported into the Philips "HighScore Plus" software[76] and compared to the reference spectra from the ICDD PDF-4 database (The International Centre for Diffraction Data, 2019). The identified peaks matches with hydroxyapatite (" $\mathrm{Ca}_{5}\left(\mathrm{PO}_{4}\right)_{3}(\mathrm{OH})$ ", reference number 04-010$6315)$ and, additionally, minor peaks of $\beta$-tricalcium phosphate $\left(\beta-\mathrm{Ca}_{3}\left(\mathrm{PO}_{4}\right)_{2}\right.$, reference number 04-008-8714) and calcium carbonate $\left(\mathrm{CaCO}_{3}\right.$, reference number 01-078-4614) were also detected. Later it was identified that the formation of calcium carbonate in the "biomorphic fibres (final product)" was likely associated with the $\mathrm{NaOH}$ washing treatment and formed by uptake of $\mathrm{CO}_{2}$ from the ambient atmosphere. Figure 13, shows the comparison of pre- and post-NaOH-washed biomorphic fibres, where it is evident that $\mathrm{CaCO}_{3}$ is appearing after the treatment.

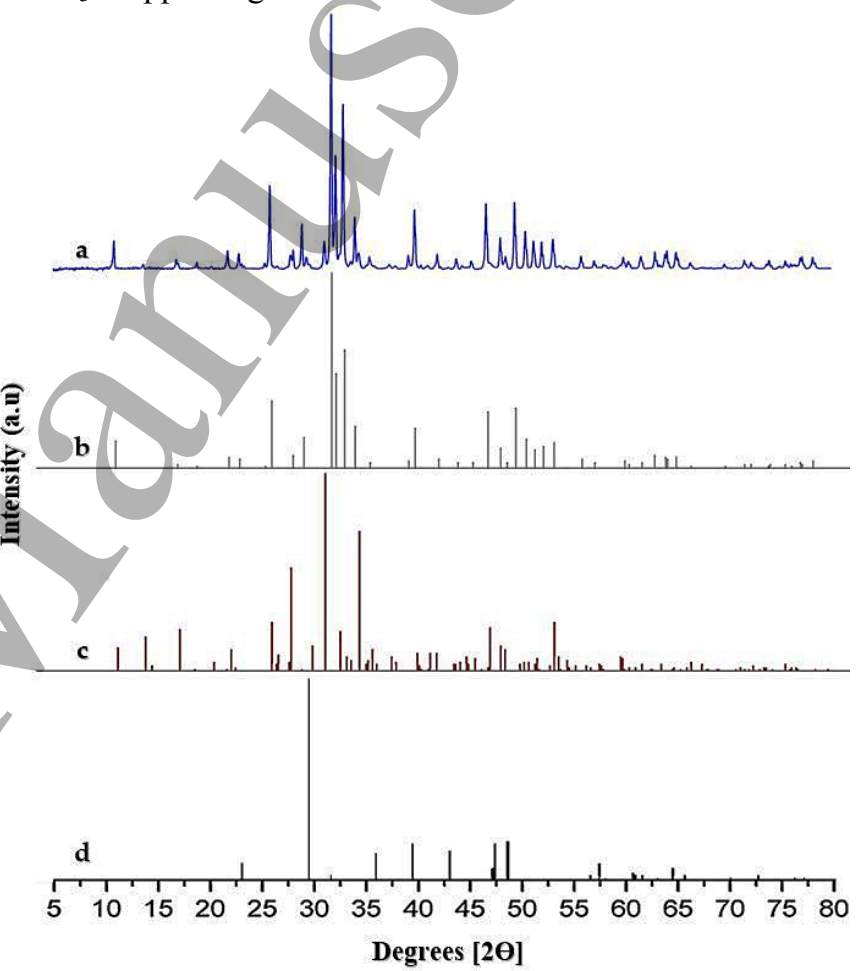

Figure 10. XRD diffractograms of (a) biomorphic fibres (final product) compared with the XRD from (b) standard

"Hydroxyapatite" (reference number 04-010-6315), (c) standard $\beta$-tri calcium phosphate (reference number 04-0088714 ) and (d) standard calcium carbonate (reference number 01-078-4614).

The Scherrer equation was used to find the mean the crystallite size (D) from the XRD line-broadening measurement for both sintered cow bone and the biomorphic fibres (final product) [59]:

$$
D=\frac{0.89 \lambda}{\beta \cos \theta}(\text { eq. 3) }
$$

Where $\lambda$ is the wavelength $(\mathrm{CuK} \alpha), \beta$ is the full width at half-maximum of the chosen diffraction line and $\theta$ the 
diffraction angle. The diffraction peak at approx. $2 \theta=25.9^{\circ}$ (corresponding to the $\left(\begin{array}{lll}0 & 0 & 2\end{array}\right)$ Miller plane) was chosen for calculating crystallite size (D), as this was found to be sufficiently isolated from the other peaks to allow measurement, as well as being sharper and more representative of the crystal growth along the c-axis. Similarly, the degree of crystallinity which reflects the fraction of the crystalline phase $\left(\chi_{c}\right)$ present in biomorphic fibres (final product) was calculated using equation 4 [77]:

$$
\left.\chi_{c}=1-\frac{v_{112} / 300}{I_{300}} \text { (eq. } 4\right)
$$

Where $\mathrm{I}_{300}$ is the intensity of (300) diffraction peak and $v_{112 / 300}$ is the intensity of the hollow between the $\left(\begin{array}{ll}1 & 1\end{array}\right)$ and $(3$ $00)$ diffraction peaks (measured by averaging the intensities), as seen in Figure 13. The crystallite size and degree of crystallinity was found to be $56.59 \mathrm{~nm}$ and 0.93 respectively. Rietveld refinement was also carried out using Philips "HighScore Plus" software[76, 78, 79] (based on the Rietveld code from Wiles \& Young [80]). Lattice parameters of biomorphic fibres (final product) were found to be $\mathrm{a}=\mathrm{b}=$ $9.41961 \AA$ and $\mathrm{c}=6.88476 \AA$ and upon comparison with the lattice parameters of hydroxyapatite $\mathrm{a}=\mathrm{b}=9.4218 \AA$ and $\mathrm{c}=$ $6.8813 \AA$ (taken from [81]), no major significant difference was noted. Unit cell volume was found to be $529.04 \AA^{3}$ calculated using $V=\frac{\sqrt{3}}{2} a^{2} c$, where a and $\mathrm{c}$ are the unit cell axes dimensions[82].

XRD analysis of raw and digest solution treated Harakeke fibres at different heat treatment temperatures (identified from TGA-DSC analysis) was also performed to investigate the formation of HAp. Figure 11 presents the diffraction spectra of raw Harakeke fibres, solution treated-dried fibres and the solution treated fibres heat treated in the range $120^{\circ} \mathrm{C}$ to 220 ${ }^{\circ} \mathrm{C}$ at an interval of $20^{\circ} \mathrm{C}$. The XRD pattern of raw Harakeke fibre represents a typical diffraction spectra of cellulose which is also matching with the literature [71]. The XRD pattern of solution treated-dried fibres revealed the substantial decrease in cellulose peaks and development of several other peaks, which corresponds to crystalline form of monocalcium phosphate monohydrate (PDF \# 04-011-5377). Monocalcium phosphate monohydrate (MCPM), also known as calcium dihydrogen phosphate having formula $\mathrm{Ca}\left(\mathrm{H}_{2} \mathrm{PO}_{4}\right)_{2} \cdot \mathrm{H}_{2} \mathrm{O}$, is an important member of calcium phosphate family. MCPM possesses a $\mathrm{Ca} / \mathrm{P}$ mole ratio of 0.5 and is highly acidic in nature. MCPM decomposes and converts into monetite $\left(\mathrm{CaHPO}_{4}\right)$ in water while forming free phosphoric acid. However, in one study involving spray drying of MCPM initial dissociation into monetite had been noted, however further heating of monetite to dryness resulted in the reformation of MCPM due to the reaction of monetite with the previously dissociated phosphoric acid[83]. It is believed that the reactive functional groups at the surface of Harakeke fibres may have aided the nucleation and growth of MCPM.

XRD analysis of $120^{\circ} \mathrm{C}, 140{ }^{\circ} \mathrm{C}$ and $160^{\circ} \mathrm{C}$, displayed the sequential diminishing peaks of MCPM, which is related with the conversion of MCPM into monetite and free phosphoric acid, however the phosphoric acid may have itself started to dehydrate, which resulted in its dissociation. It has been reported in the literature that when phosphoric acid is heated above $200^{\circ} \mathrm{C}$, it dehydrates and dissociates into a series of products ranging from pyrophosphoric acid $\left(\mathrm{H}_{4} \mathrm{P}_{2} \mathrm{O}_{7}\right)$ to metaphosphoric acid $\left(\mathrm{H}_{3} \mathrm{PO}_{4}\right)_{\mathrm{n}}$ [84]. XRD analysis at $180{ }^{\circ} \mathrm{C}$, $200{ }^{\circ} \mathrm{C} \& 220{ }^{\circ} \mathrm{C}$, depicts a pure and crystalline form of monetite (PDF \# 00-009-0080).

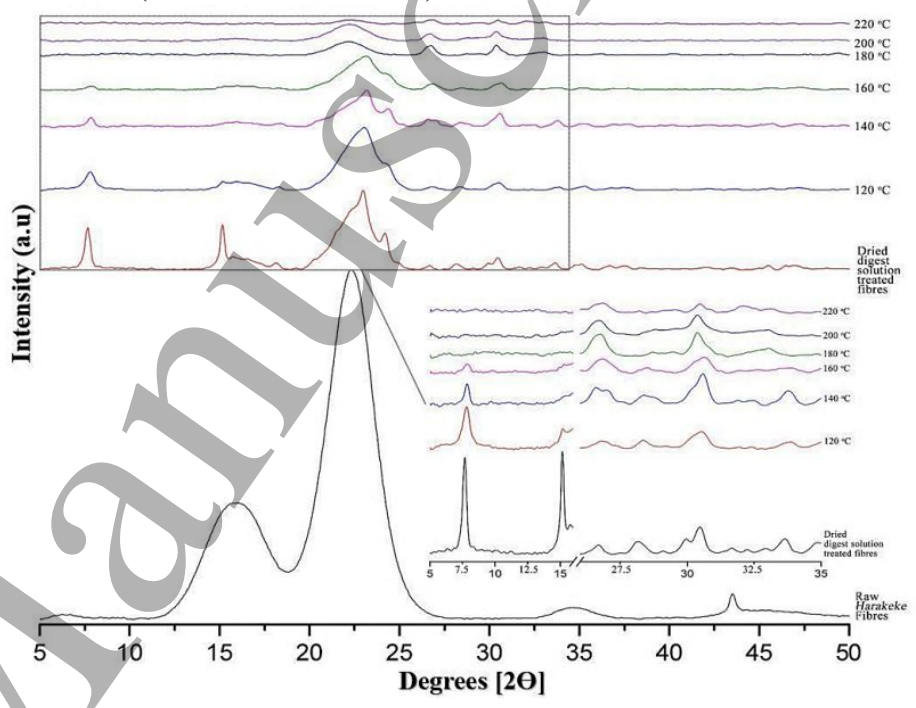

Figure 11. XRD diffractograms of raw and digest treated fibres representing evolving changes due to heating in the range from $120-220^{\circ} \mathrm{C}$

Figure 12 presents the diffraction spectra of solution treated fibres at incrementally higher temperatures. XRD analysis at 300,400 and $500{ }^{\circ} \mathrm{C}$ revealed the dissociation of monetite into poorly crystalline/amorphous calcium phosphate depicted by the presence of a broad hump in the range of $25-35^{\circ} 2 \theta$. In this range complete decomposition of the fibres' cellulose moiety also takes place. The XRD pattern obtained for fibres heated to $500^{\circ} \mathrm{C}$ represents a near complete dissociation of monetite into amorphous calcium phosphate. It is believed that the associated burning of cellulose, the releasing of $\mathrm{CO}_{2}$ and possible formation of char might have brought about conditions favourable to the transformation to HAp, as the diffraction pattern for the material heated to 600 ${ }^{\circ} \mathrm{C}$ showed the formation of poorly crystalline HAp and TCP. XRD patterns obtained of the material heated to 850 and 1000 ${ }^{\circ} \mathrm{C}$ showed an increase in the crystallinity of the formed HAp. 


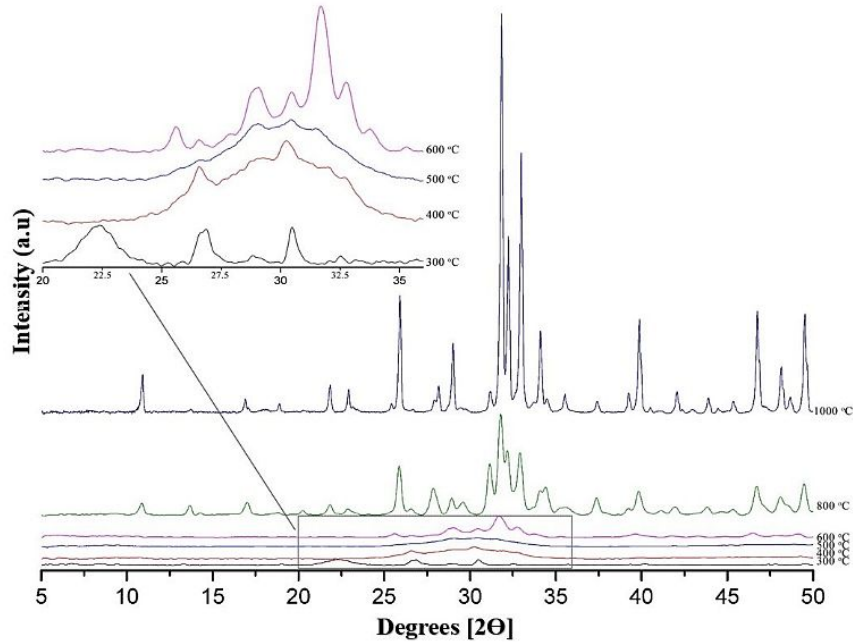

Figure 12. XRD diffractograms of raw and digest treated fibres representing the evolving phase changes occurring due to heating in the range of $300-1000{ }^{\circ} \mathrm{C}$

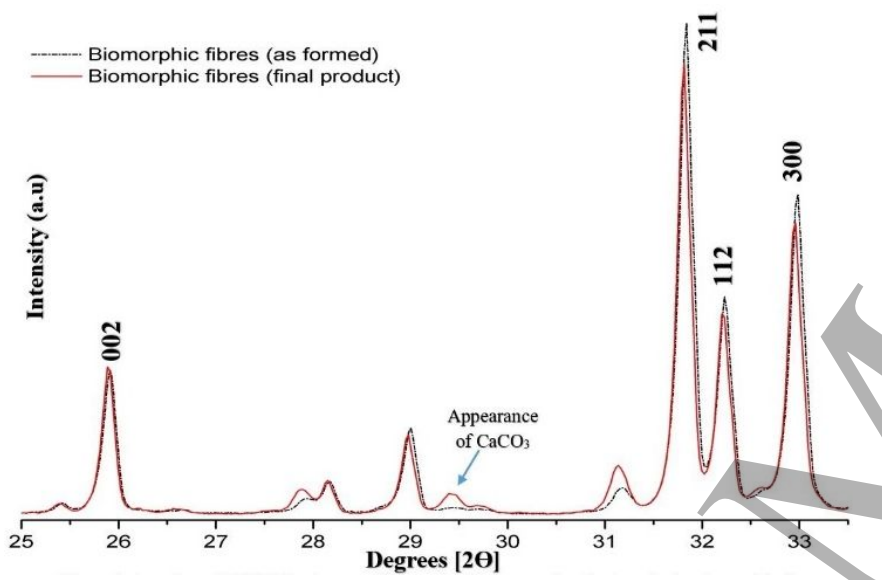

Figure 13. A portion of the XRD diffractogram of biomorphic fibres, revealing the important peaks used for the calculations of the crystallite size and degree of crystallinity.

\subsection{Imaging}

Microscopic characterisation was carried out to study the structures and morphology of the as-received Harakeke raw fibres, mild alkali-treated Harakeke fibres and biomorphic fibres (final product). Microscopic imaging of as-received (Figure 14) and $0.5 \mathrm{M} \mathrm{NaOH}$-treated Harakeke fibres (Figure 15) revealed minor fibrillation ((Figure 15 (a)), as fibres in the alkali-treated sample showed minor separation/desizing, whereas the as-received Harakeke fibres contained bundles of fibres held together by hemicellulose, lignin and pectin [46](Figure $15(a-b))$. Alkali-treated fibre surfaces were found to be more groove-like and rougher in texture (Figure 15(b)), which would be expected to give a more wettable surface [85].
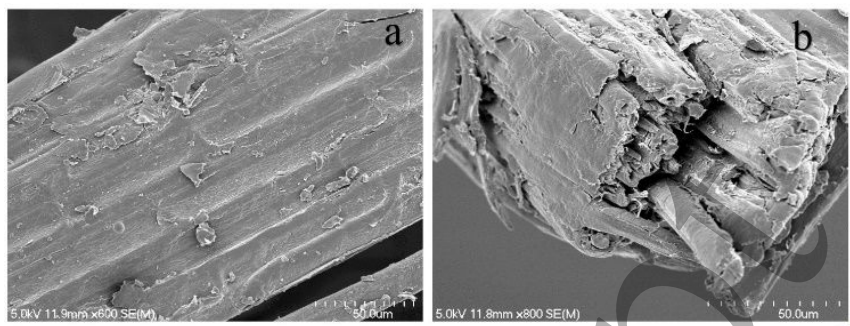

Figure 14. SEM images of as received Harakeke fibres, with (a) showing bundles of fibres and b) representing a crosssectional view of the fibre bundle in the as-received fibres.
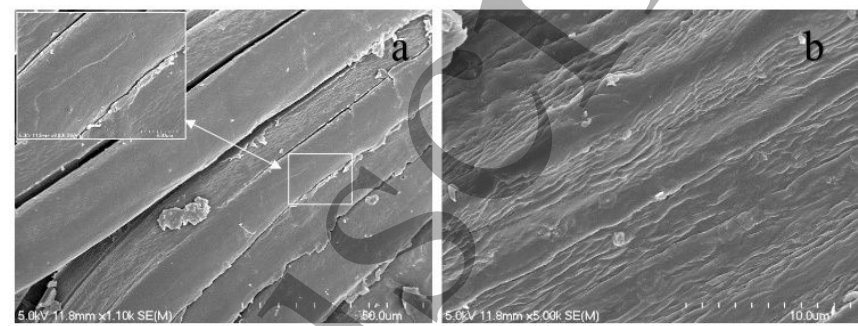

Figure 15. SEM images of the $\mathrm{NaOH}$-treated Harakeke fibres with (a) representing defibrillation in the fibres and, (b) representing surface roughness/ruggedness in the fibre.

Electron microscopic analysis of the biomorphic fibres (final product) (Figure 16) revealed the surface topology and internal/structure of fibres with their surfaces appearing smooth, but their internal structure being noticeably porous and hollow. Surface imaging also revealed the coalescence of grains along with the presence of microporosity and cracks, which is a typical result of ceramic sintering. The internal structure revealed a complex network of interconnected porosities in between several protruding structures, so resembling a fibrillar structure. The overall structure of the HAp fibres looked well developed but porous, which could be beneficial if such fibres were utilised in drug delivery or water purification systems or even as bioactive bone substitute materials in non-load bearing areas. 

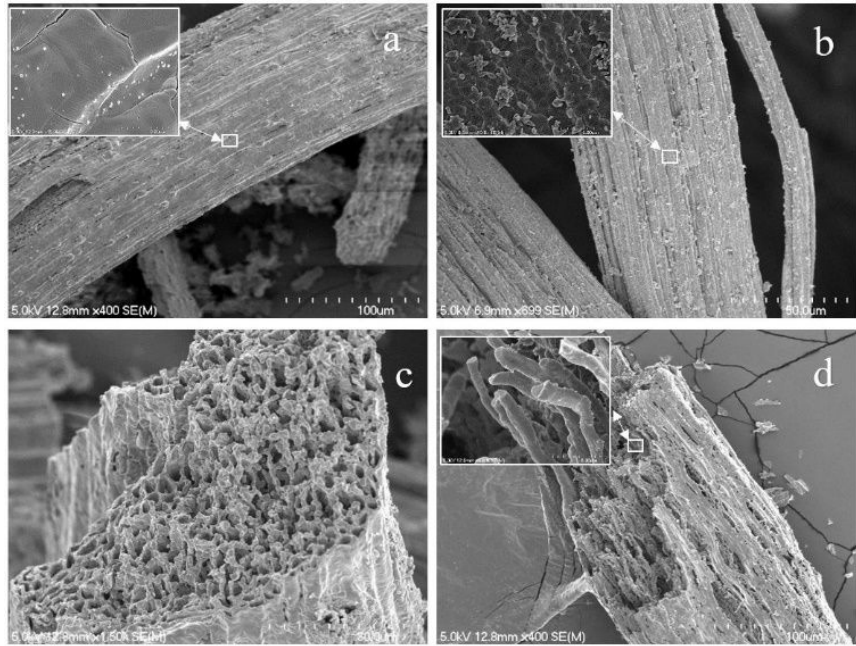

Figure 16. Electron microscopic images of Biomorphic fibres (final product) images $(a, b)$ represent surface features, while images $(c, d)$ depict internal structures and porosity.

Optical images of solution-treated fibres at different heat treatment temperatures are shown in Figure 17. Translucent MCPM deposition is clearly visible in the $100^{\circ} \mathrm{C}$ and $120^{\circ} \mathrm{C}$ samples, however, the $140{ }^{\circ} \mathrm{C}$ and $160{ }^{\circ} \mathrm{C}$ samples did not show any extra surface features on the fibres. Decolourisation of the fibres started at $160{ }^{\circ} \mathrm{C}$ and continued up to $220{ }^{\circ} \mathrm{C}$, while a deposition of an off-white solid phase identified as monetite started to appear from $180^{\circ} \mathrm{C}$. The depositions were not found to be homogenous but more patchy in nature.

Samples heat treated from $300{ }^{\circ} \mathrm{C}$, showed a white powdery surface layer on the fibres, which appeared to grow into heavy depositions up until a temperature of $600^{\circ} \mathrm{C}$. An important feature noticed at 500 and $600{ }^{\circ} \mathrm{C}$ was the charring of the fibres. Samples heated at $800{ }^{\circ} \mathrm{C}$, showed the growth of a white surface layer (composed of HAp and TCP as identified by XRD studies) on the charred fibres. Samples formed at $1000{ }^{\circ} \mathrm{C}$ showed complete formation of the biomorphic fibres.

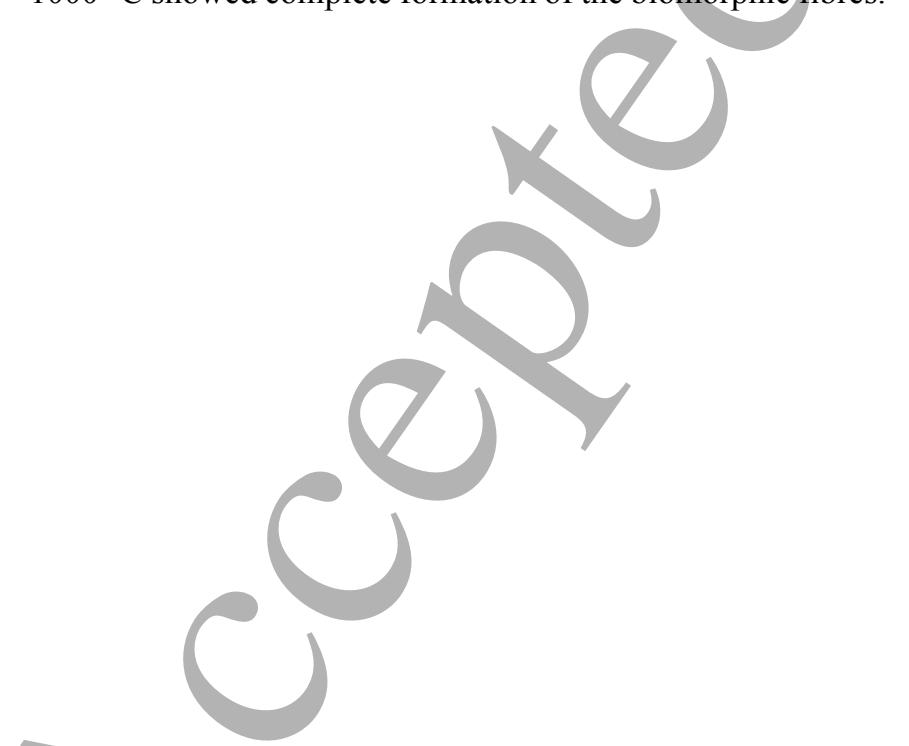

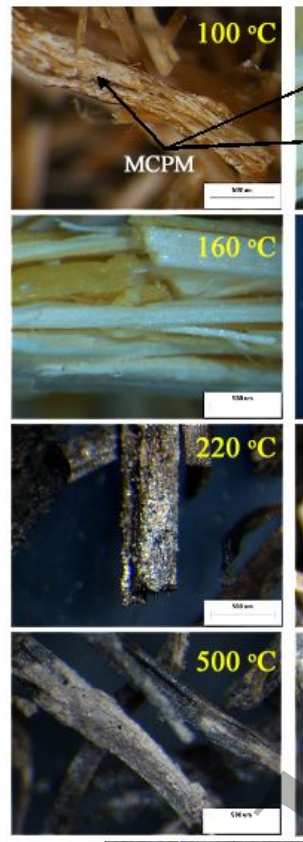
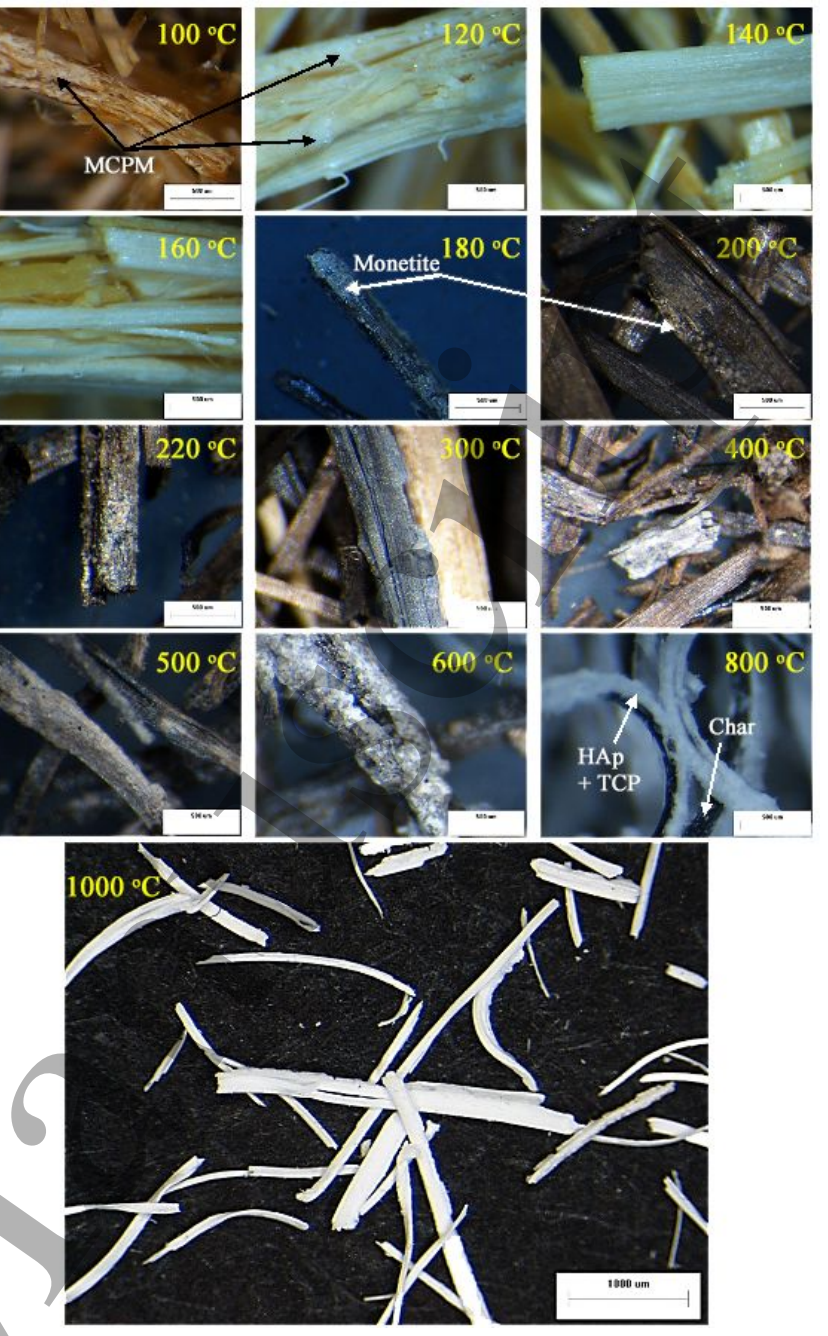

Figure 17. Optical images of digest solution treated fibres at different heating temperatures.

Hence the cast structure development of hydroxyapatite occurred along with the degradation of the fibre matrix itself, the biomorphic fibres were hence able to maintain their shape because the cast HAp assumed the morphological shape of the fibres effectively as a replica after combustive removal.

\subsection{Inductively coupled plasma-mass spectrometry (ICP-MS)}

Inductively coupled plasma-mass spectrometry (ICP-MS) has been regularly used for quantification of $\mathrm{Ca}$ and $\mathrm{P}$ in calcium phosphate samples [86-88] and is key to providing values of $\mathrm{Ca} / \mathrm{P}$ mole ratios of calcium phosphate phases present. In the present study, sintered cow bone and biomorphic fibres (as formed and final product) were dissolved in nitric acid solution, diluted, filtered and analysed by ICP-MS. The elemental composition and $\mathrm{Ca} / \mathrm{P}$ mole ratios are summarised in Table 3. The $\mathrm{Ca} / \mathrm{P}$ mole ratio of biomorphic fibre (final product) sample (analysed in triplicate) was found through testing on two independent ICP-MS instruments to be 1.48 and 
1.54. Although this is close to the value expected for tricalcium phosphate; XRD and FTIR data show clearly that HAp is present. The $\mathrm{Ca} / \mathrm{P}$ mole ratio obtained suggests that calcium deficient HAp has hence been produced. Standard XRD patterns for stoichiometric and Ca-deficient HAp are similar in appearance hence the diffractogram of biomorphic fibres (final product), Figure 10(a) can be considered to be that of calcium deficient HAp [89]. The elemental quantitative comparison of biofibre (as formed) with the sintered cow bone showed that certain elements (like $\mathrm{S}, \mathrm{Al}$, and $\mathrm{Fe}$ ) have increased quantities which is reasoned to be due to the presence of Harakeke ash. The $\mathrm{NaOH}$ washing treatment of biofibre (as formed) to produce biofibre (final product) was found to have reduced $\mathrm{Ca}$ and $\mathrm{P}$ content, while some of the ash related elements (like $\mathrm{S}$ and $\mathrm{Fe}$ ) had also reduced in amount however the $\mathrm{Na} \%$, presumably arising from the $\mathrm{NaOH}$ treatment, was found to increase.

Table 3: The elemental composition obtained using ICP-

\begin{tabular}{|c|c|c|c|c|}
\hline \multicolumn{5}{|c|}{ MS } \\
\hline Element & Unit & $\begin{array}{l}\text { Sintered } \\
\text { cow bone }\end{array}$ & $\begin{array}{c}\text { Biofibre } \\
\text { (as formed) }\end{array}$ & $\begin{array}{c}\text { Biofibre } \\
\text { (final product) }\end{array}$ \\
\hline $\mathbf{C a}$ & \multirow{10}{*}{$\%$} & 35.160 & 37.070 & 35.101 \\
\hline $\mathbf{P}$ & & 18.045 & 17.703 & 17.584 \\
\hline $\mathrm{Na}$ & & 0.669 & 0.660 & 1.660 \\
\hline Mg & & 0.491 & 0.476 & 0.452 \\
\hline $\mathbf{S}$ & & 0.157 & 0.251 & 0.176 \\
\hline $\mathrm{Sr}$ & & 0.061 & 0.050 & 0.048 \\
\hline $\mathbf{B a}$ & & 0.060 & 0.046 & 0.042 \\
\hline Al & & 0.001 & 0.025 & 0.027 \\
\hline $\mathbf{K}$ & & 0.025 & 0.020 & 0.017 \\
\hline $\mathrm{Fe}$ & & 0.002 & 0.011 & 0.010 \\
\hline $\begin{array}{c}\mathrm{Ca} / \mathrm{P} \text { mole } \\
\text { ratio }\end{array}$ & -- & 1.54 & 1.62 & 1.54 \\
\hline
\end{tabular}

\section{Conclusions}

This research reports the novel formation of calcium deficient biomorphic HAp fibres via an aqueous soaking technique of Harakeke Fibres in a bovine digest solution followed by calcination. Bovine bone was used as a biogenic source of $\mathrm{Ca}^{2+}$ and $\mathrm{PO}_{4}{ }^{3-}$ ions instead of resorting to the use of commercial HAp powder. This approach potential allows repurposing of agricultural by-products. Harakeke fibres were used as a unique biotemplate due to their abundance in nature and thermal stability (up to $200{ }^{\circ} \mathrm{C}$ ). These allowed the development of potentially useful bio-inspired biomedical materials from the natural plant fibres. The final product realised was not only able to retain the original shape of the Harakeke fibres but was also found to form a phase of bone like apatite in the form of a porous matrix that could be used as a xenografting material.

\section{Acknowledgements}

The authors would like to acknowledge Mr Wiremu Puke for his cultural support of the project. Humair Ahmed Siddiqui also gratefully acknowledges the University of Waikato for a University of Waikato Doctoral Scholarship and would also like to acknowledge NED University of Engg. and Tech. for facilitating higher studies in New Zealand.

\section{Conflicts of Interest:}

The authors declare no conflicts of interest.

\section{References}

[1] Glaser D E and Viney C 2013 Biomimetic Materials Biomaterials Science 349-60

[2] Ripley R L and Bhushan B 2016 Bioarchitecture: bioinspired art and architecture--a perspective Philos Trans A Math Phys Eng Sci 37420160192

[3] Paris O, Burgert I and Fratzl P 2010 Biomimetics and Biotemplating of Natural Materials 35 219-25

[4] Dong Q, Su H, Cao W, Zhang D, Guo Q and Lai Y 2007 Synthesis and characterizations of hierarchical biomorphic titania oxide by a bio-inspired bottom-up assembly solution technique Journal of Solid State Chemistry $180949-55$

[5] Studart A R, Gonzenbach U T, Tervoort E and Gauckler L J 2006 Processing Routes to Macroporous Ceramics: A Review J. Am. Ceram. Soc. 89 1771-89

[6] Luo M, Gao J Q, Qiao G J and Jin Z H 2008 Synthesis of wood-derived ceramics from biological templates Prog. Chem. 20 989-1000

[7] Ramírez-Rico J, Martínez-Fernandez J and Singh M 2017 Biomorphic ceramics from wood-derived precursors Int. Mater. Rev. 62 465-85

[8] Baino F and Ferraris M 2017 Learning from Nature: Using bioinspired approaches and natural materials to make porous bioceramics International Journal of Applied Ceramic Technology 14 507-20

[9] Gonzalez P, Serra J, Liste S, Chiussi S, Leon B, PerezAmor M, Martinez-Fernandez J, de Arellano-Lopez A R and Varela-Feria F M 2003 New biomorphic SiC ceramics coated with bioactive glass for biomedical applications Biomaterials 24 4827-32

[10] Rambo C, Müller F, Müller L, Sieber H, Hofmann I and Greil P 2006 Biomimetic Apatite Coating on Biomorphous Alumina Scaffolds 26 92-9

[11] Wu S, Liu X, Yeung K W K, Liu C and Yang X 2014 Biomimetic porous scaffolds for bone tissue engineering Materials Science and Engineering: R: Reports 80 1-36

[12] Neto A S and Ferreira J M F 2018 Synthetic and MarineDerived Porous Scaffolds for Bone Tissue Engineering Materials (Basel) 111702

[13] Zhang K, Fan Y, Dunne N and Li X 2018 Effect of microporosity on scaffolds for bone tissue engineering Regen Biomater 5 115-24

[14] Siddiqui H A, Pickering K L and Mucalo M R 2018 A Review on the Use of Hydroxyapatite-Carbonaceous Structure Composites in Bone Replacement Materials for Strengthening Purposes Materials 111813 

1 17-22 75 221-8 Japan 95 825-7 $1183717-23$
[15] LeGeros R Z 2002 Properties of osteoconductive biomaterials: calcium phosphates Clinical orthopaedics and related research $39581-98$

[16] Gu Y W, Khor K A and Cheang P 2004 Bone-like apatite layer formation on hydroxyapatite prepared by spark plasma sintering (SPS) Biomaterials 25 4127-34

[17] Kim H M, Himeno T, Kawashita M, Kokubo T and Nakamura T 2004 The mechanism of biomineralization of bone-like apatite on synthetic hydroxyapatite: an in vitro assessment Journal of the Royal Society, Interface

[18] Czikó M, Bogya E-S, Barabás R, Bizo L and Stefan R 2013 In vitro biological activity comparison of some hydroxyapatite-based composite materials using simulated body fluid Open Chemistry 11 1583-98

[19] C. B. M. Fook A, A.H A, Fideles T, C. Costa R and Fook M 2009 Porous Hydroxyapatite Scaffolds by Polymer Sponge Method 396-398 703-6

[20] Johnson G S, Mucalo M R and Lorier M A 2000 The processing and characterization of animal-derived bone to yield materials with biomedical applications: part 1: modifiable porous implants from bovine condyle cancellous bone and characterization of bone materials as a function of processing Journal of materials science. Materials in medicine 11 427-41

[21] Lee J-H and Kim Y-J 2014 Hydroxyapatite nanofibers fabricated through electrospinning and sol-gel process Ceramics International 40 3361-9

[22] G R, S B, Venkatesan B and Vellaichamy E 2017 A novel nano-hydroxyapatite - PMMA hybrid scaffolds adopted by conjugated thermal induced phase separation (TIPS) and wet-chemical approach: Analysis of its mechanical and biological properties Materials science $\&$ engineering. C, Materials for biological applications

[23] Hattori T, Iwadate Y, Inai H, Sato K and Imai Y 1987 Preparation of Hydroxyapatite Powder-Using a FreezeDrying Method Journal of the Ceramic Association,

[24] Sepulveda P, Binner J, Rogero S, Higa O and Bressiani J 2000 Production of Porous Hydroxyapatite by the GelCasting of Foams and Cytotoxic Evaluation 50 27-34

[25] Carreño N L V, Rattman C W R, Gonçalves M R F, Silva R M e, Paganotto G F d R, Alcazar J C B, Avellaneda C O, Barbosa A M, Duarte V C and Lucena P R d 2016 Nano and Micro Ceramic Membranes from Degradable Templates Materials Research 19 1017-25

[26] Utara S and Klinkaewnarong J 2016 Synthesis and characterization of hydroxyapatite nanoparticles templated by ozonolysed natural rubber latex Journal of Sol-Gel Science and Technology 80 728-37

[27] Verma G, Barick K C, Manoj N, Sahu A K and Hassan P A 2013 Rod-like micelle templated synthesis of porous hydroxyapatite Ceramics International 39 8995-9002

[28] Yin X and Stott M J 2003 Biological calcium phosphates and Posner's cluster The Journal of Chemical Physics
[29] Mancardi G, Hernandez Tamargo C E, Di Tommaso D and de Leeuw N H 2017 Detection of Posner's clusters during calcium phosphate nucleation: a molecular dynamics study J Mater Chem B 5 7274-84

[30] Pan H, Liu X Y, Tang R and Xu H Y 2010 Mystery of the transformation from amorphous calcium phosphate to hydroxyapatite Chem Commun (Camb) 46 7415-7

[31] Dorozhkin S V 2010 Amorphous calcium (ortho)phosphates Acta Biomater 6 4457-75

[32] Posner A S and Betts F 2002 Synthetic amorphous calcium phosphate and its relation to bone mineral structure Accounts of Chemical Research 8 273-81

[33] Onuma K and Ito A 1998 Cluster Growth Model for Hydroxyapatite Chemistry of Materials 10 3346-51

[34] Wang L, Li S, Ruiz-Agudo E, Putnis C V and Putnis A 2012 Posner's cluster revisited: direct imaging of nucleation and growth of nanoscale calcium phosphate clusters at the calcite-water interface CrystEngComm 14 6252-6

[35] Habraken W J, Tao J, Brylka L J, Friedrich H, Bertinetti L, Schenk A S, Verch A, Dmitrovic V, Bomans P H, Frederik P M, Laven J, van der Schoot P, Aichmayer B, de With G, DeYoreo J J and Sommerdijk N A 2013 Ionassociation complexes unite classical and non-classical theories for the biomimetic nucleation of calcium phosphate Nat Commun 41507

[36] Combes C and Rey C 2010 Amorphous calcium phosphates: synthesis, properties and uses in biomaterials Acta Biomater 6 3362-78

[37] Onuma K and Sugiura Y 2015 Metastable Intermediate Phase during Phase Transformation of Calcium Phosphates Journal of Biotechnology \& Biomaterials 05 214

[38] Aho A, Rekola J, Matinlinna J, Gunn J, Tirri T, Viitaniemi P and Vallittu P 2007 Natural composite of wood as replacement material for ostechondral bone defects 83 64-71

[39] Wehi P M and Clarkson B D 2010 Biological flora of New Zealand 10.Phormium tenax, harakeke, New Zealand flax N. Z. J. Bot. 45 521-44

[40] Carr D J, Cruthers N M, Laing R M and Niven B E 2016 Fibers from Three Cultivars of New Zealand Flax (Phormium tenax) Text. Res. J. 75 93-8

[41] Daniels V 2013 Factors affecting the deterioration of the cellulosic fibres in black-dyed New Zealand flax (phormium tenax) Studies in Conservation 44 73-85

[42] Ansell M P and Mwaikambo L Y 2009 Handbook of Textile Fibre Structure, ed S J Eichhorn, et al:: Woodhead Publishing) pp 62-94

[43] Duchemin B, Luijk K and Staiger M 2003 New Zealand Flax (Phormium tenax) Reinforced Eco-Composites. In: 2nd international conference on eco-composites, (Queen Mary, University of London, London, UK

[44] Alzeer M and MacKenzie K 2013 Synthesis and mechanical properties of novel composites of inorganic polymers (geopolymers) with unidirectional natural flax fibres (phormium tenax) Applied Clay Science 75-76 $148-52$ 
[45] De Rosa I M, Santulli C and Sarasini F 2010 Mechanical and thermal characterization of epoxy composites reinforced with random and quasi-unidirectional untreated Phormium tenax leaf fibers Materials \& Design (1980-2015) 31 2397-405

[46] Duchemin B and Staiger M P 2009 Treatment of Harakeke fiber for biocomposites Journal of Applied Polymer Science 112 2710-5

[47] Puglia D, Monti M, Santulli C, Sarasini F, De Rosa I M and Kenny J M 2013 Effect of alkali and silane treatments on mechanical and thermal behavior of Phormium tenax fibers Fibers and Polymers 14 423-7

[48] Lowe B J, Smith C A, Fraser-Miller S J, Paterson R A, Daroux F, Ngarimu-Cameron R, Ford B and Gordon K C 2017 Light-ageing characteristics of Māori textiles: Colour, strength and molecular change Journal of Cultural Heritage 24 60-8

[49] Fortunati E, Puglia D, Monti M, Peponi L, Santulli C, Kenny J M and Torre L 2012 Extraction of Cellulose Nanocrystals from Phormium tenax Fibres Journal of Polymers and the Environment 21 319-28

[50] Mucalo M and Foster D 2004 A method for avoiding the xanthoproteic-associated discolouration in reprecipitated (nitric-acid-digested) hydroxyapatite prepared from mammalian bone tissue Croatica Chemica Acta 77509

[51] Barakat N A M, Khil M S, Omran A M, Sheikh F A and Kim H Y 2009 Extraction of pure natural hydroxyapatite from the bovine bones bio waste by three different methods Journal of Materials Processing Technology 209 3408-15

[52] Akindoyo J O, Ghazali S, Beg M D H and Jeyaratnam N 2019 Characterization and Elemental Quantification of Natural Hydroxyapatite Produced from Cow Bone Chemical Engineering \& Technology 42 1805-15

[53] Mucalo M R 2015 Animal-bone derived hydroxyapatite in biomedical applications Hydroxyapatite (Hap) for Biomedical Applications 307-42

[54] Ren F, Ding Y and Leng Y 2014 Infrared spectroscopic characterization of carbonated apatite: a combined experimental and computational study $J$ Biomed Mater Res A 102 496-505

[55] Ren F Z and Leng Y 2011 Carbonated Apatite, Type-A or Type-B? Key Engineering Materials 493-494 293-7

[56] Matsumura Y and Moffat J B 1994 Partial Oxidation of Methane to Carbon-Monoxide and Hydrogen with Molecular-Oxygen and Nitrous-Oxide over Hydroxyapatite Catalysts Journal of Catalysis 148 32333

[57] Cheng Z H, Yasukawa A, Kandori K and Ishikawa $T$ 1998 FTIR Study of Adsorption of CO2on Nonstoichiometric Calcium Hydroxyapatite Langmuir 14 6681-6

[58] Raynaud S, Champion E, Bernache-Assollant D and Thomas P 2002 Calcium phosphate apatites with variable $\mathrm{Ca} / \mathrm{P}$ atomic ratio I. Synthesis, characterisation and thermal stability of powders Biomaterials 231065 72

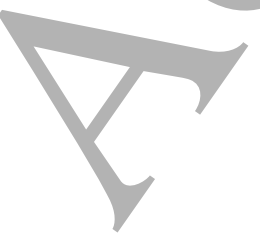

[59] Reyes-Gasga J, Martínez-Piñeiro E, Rodríguez-Álvarez G, E Tiznado-Orozco G, García-García R and Bres E 2013 XRD and FTIR crystallinity indices in sound human tooth enamel and synthetic hydroxyapatite $\mathbf{3 3}$ 4568-74

[60] Weiner S and Bar-Yosef O 1990 States of preservation of bones from prehistoric sites in the Near East: A survey Journal of Archaeological Science 17 187-96

[61] Koutsopoulos S 2002 Synthesis and characterization of hydroxyapatite crystals: a review study on the analytical methods J Biomed Mater Res 62 600-12

[62] De Aza P, Guitian F, Santos C, De Aza S, Cusco R and Artus L 1997 Vibrational properties of calcium phosphate compounds. 2. Comparison between hydroxyapatite and $\beta$-tricalcium phosphate Chemistry of Materials 9 916-22

[63] Farlay D, Panczer G, Rey C, Delmas P D and Boivin G 2010 Mineral maturity and crystallinity index are distinct characteristics of bone mineral Journal of bone and mineral metabolism 28 433-45

[64] Rey C, Marsan O, Combes C, Drouet C, Grossin D and Sarda S 2014 Advances in Calcium Phosphate Biomaterials, ed B Ben-Nissan (Berlin, Heidelberg: Springer Berlin Heidelberg) pp 229-66

[65] Wong W Y and Noor A-F M 2016 Synthesis and Sintering-wet Carbonation of Nano-sized Carbonated Hydroxyapatite Procedia Chemistry 19 98-105

[66] Mandair G S and Morris M D 2015 Contributions of Raman spectroscopy to the understanding of bone strength Bonekey Rep 4620

[67] Morris M D and Mandair G S 2011 Raman assessment of bone quality Clinical orthopaedics and related research $4692160-9$

[68] Sa Y, Guo Y, Feng X, Wang M, Li P, Gao Y, Yang X and Jiang T 2017 Are different crystallinity-indexcalculating methods of hydroxyapatite efficient and consistent? New Journal of Chemistry 41 5723-31

[69] Li Z and Pasteris J D 2014 Chemistry of bone mineral, based on the hypermineralized rostrum of the beaked whale Mesoplodon densirostris The American mineralogist 99 645-53

[70] Rojas J, Bedoya M and Ciro Y 2015 Current Trends in the Production of Cellulose Nanoparticles and Nanocomposites for Biomedical Applications Cellulose - Fundamental Aspects and Current Trends 193-228

[71] Aruan Efendy M G and Pickering K L 2014 Comparison of harakeke with hemp fibre as a potential reinforcement in composites Composites Part A: Applied Science and Manufacturing 67 259-67

[72] Puglia D, Santulli C, Sarasini F, Kenny J M and Valente T 2013 Thermal and mechanical characterisation ofPhormium tenax-reinforced polypropylene composites Journal of Thermoplastic Composite Materials 27 1493503

[73] Wang T, Kong S, Jia Y, Chang L, Wong C P and Xiong D 2013 Synthesis and Thermal Conductivities of the Biomorphic A12O3 Fibers Derived from Silk Template 10 285-92 
[74] Liu W, Mohanty A K, Drzal L T, Askel P and Misra M 2004 Effects of alkali treatment on the structure, morphology and thermal properties of native grass fibers as reinforcements for polymer matrix composites Journal of Materials Science 39 1051-4

[75] Albano C, González J, Ichazo M and Kaiser D 1999 Thermal stability of blends of polyolefins and sisal fiber Polymer Degradation and Stability 66 179-90

[76] Degen T, Sadki M, Bron E, König U and Nénert G 2014 The HighScore suite Powder Diffraction 29 S13-S8

[77] Landi E, Tampieri A, Celotti G and Sprio S 2000 Densification behaviour and mechanisms of synthetic hydroxyapatites Journal of the European Ceramic Society $202377-87$

[78] Friederichs R J, Chappell H F, Shepherd D V and Best S M 2015 Synthesis, characterization and modelling of zinc and silicate co-substituted hydroxyapatite $J R S o c$ Interface 1220150190

[79] Moslim N A, Ahmad N and Kasim S R 2018 XRD Analysis of Calcined Magnesium Substituted Biphasic Calcium Phosphate (Mg-BCP) Journal of Physics: Conference Series 1082012025

[80] Wiles D B and Young R A 1981 A new computer program for Rietveld analysis of X-ray powder diffraction patterns Journal of Applied Crystallography 14 149-51

[81] Rodríguez-Lorenzo L M, Hart J N and Gross K A 2003 Structural and Chemical Analysis of Well-Crystallized Hydroxyfluorapatites The Journal of Physical Chemistry B 107 8316-20

[82] Tilley R J D 2006 Crystals and Crystal Structures: Wiley)

[83] Nasri K, El Feki H, Sharrock P, Fiallo M and Nzihou A 2015 Spray-Dried Monocalcium Phosphate Monohydrate for Soluble Phosphate Fertilizer Industrial \& Engineering Chemistry Research 54 8043-7

[84] Considine G D 2006 Van Nostrand's Scientific Encyclopedia, ed G D Considine

[85] Chen H, Zhang W, Wang X, Wang H, Wu Y, Zhong T and Fei B 2018 Effect of alkali treatment on wettability and thermal stability of individual bamboo fibers Journal of Wood Science 64 398-405

[86] Giraldo-Betancur A L, Espinosa-Arbelaez D G, RealLópez A d, Millan-Malo B M, Rivera-Muñoz E M, Gutierrez-Cortez E, Pineda-Gomez P, Jimenez-Sandoval S and Rodriguez-García M E 2013 Comparison of physicochemical properties of bio and commercial hydroxyapatite Current Applied Physics 13 1383-90

[87] Wang Y, Yao A, Huang W, Wang D and zhou J 2011 In situ fabrication of hollow hydroxyapatite microspheres by phosphate solution immersion Journal of Crystal Growth 327 245-50

[88] Salma-Ancane K, Stipniece L and Irbe Z 2016 Effect of biogenic and synthetic starting materials on the structure of hydroxyapatite bioceramics Ceramics International 42 9504-10

[89] Beaufils S, Rouillon T, Millet P, Le Bideau J, Weiss P, Chopart J P and Daltin A L 2019 Synthesis of calcium- deficient hydroxyapatite nanowires and nanotubes performed by template-assisted electrodeposition Materials science \& engineering. C, Materials for biological applications $98333-46$

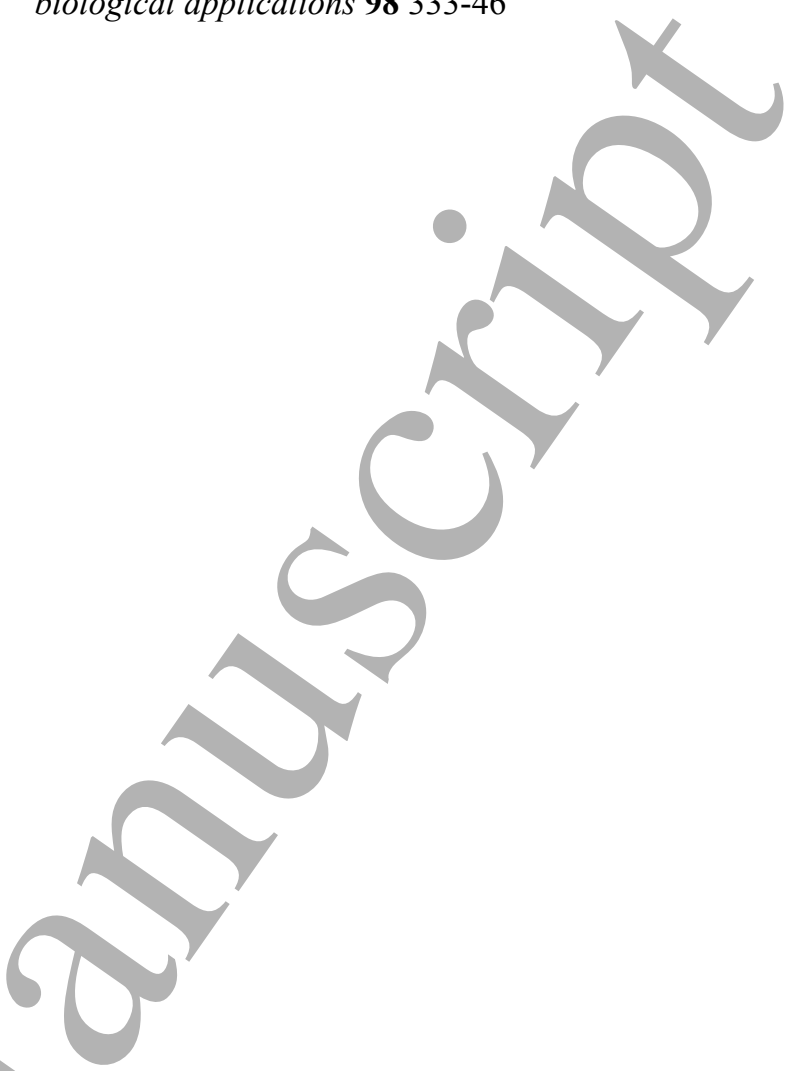

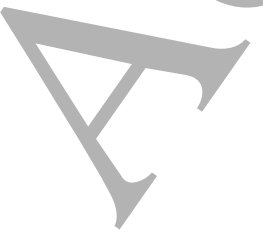

